\title{
Sharing Lisboa: A Digital Social Market to Promote Sustainable and Energy Efficient Behaviours
}

\author{
Catarina C. Rolim ${ }^{1}$ (D) and Patrícia Baptista ${ }^{2, *(D)}$ \\ 1 IN+, Center for Innovation, Technology and Policy Research, Instituto Superior Técnico, \\ Universidade de Lisboa, 1049-001 Lisbon, Portugal; catarina.rolim@tecnico.ulisboa.pt \\ 2 IN+, Center for Innovation, Technology and Policy Research, Associação para o Desenvolvimento do Instituto \\ Superior Técnico, Universidade de Lisboa, 1049-001 Lisbon, Portugal \\ * Correspondence: patricia.baptista@tecnico.ulisboa.pt
}

check for updates

Citation: Rolim, C.C.; Baptista, P. Sharing Lisboa: A Digital Social Market to Promote Sustainable and Energy Efficient Behaviours. Climate 2021, 9, 34. https://doi.org/ $10.3390 /$ cli9020034

Received: 22 January 2021

Accepted: 18 February 2021

Published: 21 February 2021

Publisher's Note: MDPI stays neutral with regard to jurisdictional claims in published maps and institutional affiliations.

Copyright: (C) 2021 by the authors. Licensee MDPI, Basel, Switzerland. This article is an open access article distributed under the terms and conditions of the Creative Commons Attribution (CC BY) license (https:// creativecommons.org/licenses/by/ $4.0 /)$.

\begin{abstract}
Several solutions and city planning policies have emerged to promote climate change and sustainable cities. The Sharing Cities program has the ambition of contributing to climate change mitigation by improving urban mobility, energy efficiency in buildings and reducing carbon emissions by successfully engaging citizens and fostering local-level innovation. A Digital Social Market (DSM), named Sharing Lisboa, was developed in Lisbon, Portugal, supported by an application (APP), enabling the exchange of goods and services bringing citizens together to support a common cause: three schools competing during one academic year (2018/2019) to win a final prize with the engagement of school community and surrounding community. Sharing Lisboa aimed to promote behaviour change and the adoption of energy-saving behaviours such as cycling and walking with the support of local businesses. Participants earned points that reverted to the cause (school) they supported. A total of 1260 users was registered in the APP, collecting more than 850,000 points through approximately 17,000 transactions. This paper explores how the DSM has the potential to become a new city service promoting its sustainable development. Furthermore, it is crucial for this concept to reach economic viability through a business model that is both profitable and useful for the city, businesses and citizens, since investment will be required for infrastructure and management of such a market.
\end{abstract}

Keywords: energy efficiency; sustainable mobility; behaviours; sustainable community

\section{Introduction}

Nowadays, cities are growing in size and population, leading to challenges related to demographics, climate change, energy consumption, transportation, among others, jeopardizing the resilience of urban systems and social wellbeing. The Lisbon Metropolitan area has seen a population increase of 5.7\% from 2001 to 2017 [1]. Several solutions and city planning strategies have emerged to overturn these challenges and promote the sustainable development of cities, focusing on changing behaviour towards energy efficiency improvements, achieving the targets imposed by the 2030 climate and energy framework to decrease greenhouse gas emissions by at least $40 \%$ compared to 1990 levels; introduce a renewable energy share of at least $27 \%$; and promote an improvement in energy efficiency of at least $27 \%$ [2].

Over the last years, the city of Lisbon promoted the implementation of several sustainable urban mobility and building energy efficiency services in order to reach the targets proposed. These services include: the introduction in 2017 of a bike-sharing service with electric bikes; the deployment of electric vehicles charging stations; adoption of alternative vehicle technologies by the municipal fleet with $39 \%$ of municipal fleet composed by electric vehicles, compared to a $36 \%$ increase in electric vehicle sales in Portugal from 2017 to 2018 [3]; introduction of smart meters for energy monitoring at a residential level; 
installation of PVs, among others. As a result, Lisbon was ranked in the 14th position in a smart and sustainable ranking of 28 European capital cities [4].

With the growth of such solutions and services, the levels of digitalization and the amount of urban data have also been increasing, leaving city leaders and operators, including public and private organizations and companies, with the challenge of deciding how these data will be collected, stored used and shared [5]. The added value that the amount of data collected can be applied by different types of users (e.g., public entities, private companies, academics, citizens) and for several purposes (e.g., new software, new services, policy-making). Consequently, smart city planning must involve new stakeholder groups which will add complexity to the process and, therefore, a new type of governance in smart city planning is required. With the number of stakeholders involved, it is essential to: have clarity when outlining the plan and identify each stakeholder responsibility and role [6]; promoting a culture of data sharing and transparency, reflected on potential data products and services; and consider data ownership, governance and policy factors [7]. Cities and the lives of their citizens are, therefore, changing and evolving with impacts mainly related with governance, policies, culture and, consequently, start training and reskilling workers and test new technologies, enabling a complex process of digital transition $[7,8]$.

Information and communication technologies (ICT) are an essential tool to enable the sustainable transformation of smart cities, presenting innovative approaches to address urban challenges [9]. However, ICT are frequently selected before understanding if they will address the underlying needs of citizens [10]. As such, smart cities' degrees of success vary significantly and their full potential is not reached due to a lack of citizens' involvement [11]

Consequently, the topic of citizen engagement in urban processes starts to be tackled, since it becomes of crucial importance to involve the citizens in this transformation process promoting the adoption of sustainable behaviours improving quality of life and leading to the transformation of urban contexts [12]. While the assessment of city approaches and their impact outcomes provide insights on smart city evaluation, they do not take into account the inputs from citizens even though they recognize their crucial role in the design of measures [13].

The growth of digitalization levels within cities has enabled the practice of democratic governance through e-participation. However, engagement in such activities is difficult to acquire since its effect are most of the time invisible to the participants or take a long time to appear. Participation through gamification has revealed increases in engagement, motivation, civic learning and enjoyment [14]. As such, gamification can be a crucial tool to adopt when designing services to promote behaviour change and the adoption of more sustainable behaviours, since it has the potential to interest and motivate the community to participate in city life [15]. Environmental sustainability is among the domains in which gamification has demonstrated positive impacts when applied to promote socially beneficial behaviours, applied to promote energy savings and sustainable buildings [16] and sustainable mobility [17]. Within the scope of the STREETLIFE EU project, the Rovereto Play\&Go game aimed to assess the impact of gamification techniques and incentives on mobility behaviour with results indicating that the game had induced a change in the participants' mobility habits [17]. A game network involving schools in 19 European member states promoting sustainable mobility modes achieved a $15 \%$ shift in trips made by car to more sustainable modes such as walking and cycling, among others [18]. In Switzerland, the Bellidea smartphone APP deployed in the city of Bellinzona to promote sustainable mobility reached 600 users of which 180 used the APP functions on a daily basis [19]. The enCOMPASS project developed an APP to motivate behavioural changes combining team competition, virtual rewards and life simulation with the goal of achieving energy savings in households and public buildings. Preliminary results indicated energy consumption reductions between 10 to $12 \%$ in residential consumers [20]. The GAIA project [21] developed a platform installed in schools with the goal of increasing sustainability awareness and energy efficiency through gamification. With the participation of over 3000 students and 200 educators, energy savings between 15 and 20\% were reached. 
The ChArGED project [22] aimed to promoted energy efficiency and reduction of wasted energy in public buildings through an APP that provided users with real-time recommendations and in-game challenges. Users self-reported an improvement of $9.61 \%$ of energy savings. Furthermore, users also were very satisfied with the game APP. A summary of these projects is presented in Table 1.

Table 1. Summary of projects on user engagement.

\begin{tabular}{|c|c|c|c|c|c|}
\hline Project (Year) & Where & Type & Who & How & Results \\
\hline \multicolumn{6}{|c|}{ Mobility } \\
\hline $\begin{array}{l}\text { STREETLIFE EU } \\
(2013-2016) \text { [17] }\end{array}$ & $\begin{array}{l}\text { Germany, Finland, } \\
\text { Italy }\end{array}$ & $\begin{array}{l}\text { Service-based } \\
\text { gamification } \\
\text { framework }\end{array}$ & Citizens & $\begin{array}{l}\text { - } \quad \text { Incentivize } \\
\text { voluntary } \\
\text { behavioural } \\
\text { changes } \\
\text { towards } \\
\text { sustainable } \\
\text { mobility } \\
\text { solutions }\end{array}$ & $\begin{array}{l}\text { - Gamification in- } \\
\text { centivized play- } \\
\text { ers to use their } \\
\text { private cars less } \\
\text { Potential of } \\
\text { gamification to } \\
\text { promote sus- } \\
\text { tainable urban } \\
\text { mobility policies }\end{array}$ \\
\hline $\begin{array}{c}\text { Traffic Snake } \\
\text { Game Network } \\
\text { (TSG NETWORK) } \\
(2014-2017)[18]\end{array}$ & $\begin{array}{l}19 \text { European } \\
\text { Member States }\end{array}$ & Game & $\begin{array}{l}\text { Children (6-12) } \\
\text { and parents }\end{array}$ & $\begin{array}{l}\text { - Shifting } \\
\text { journeys un- } \\
\text { dertaken by } \\
\text { car to more } \\
\text { sustainable } \\
\text { modes such } \\
\text { as walking, } \\
\text { cycling, pub- } \\
\text { lic transport, } \\
\text { park and } \\
\text { walk and car } \\
\text { sharing }\end{array}$ & $\begin{array}{l}177,587 \text { pupils } \\
\text { in } 1192 \text { schools } \\
\text { played the game. } \\
\text { EU-wide savings } \\
\text { in this period } \\
\text { reached } 2,458,853 \\
\text { kilometres of } \\
\text { car trips and } 397 \\
\text { tonnes of } \mathrm{CO}_{2} . \\
\text { Sustainable trips } \\
\text { went from } 63 \% \\
\text { before the cam- } \\
\text { paign to } 78 \% \text { dur- } \\
\text { ing the campaign. }\end{array}$ \\
\hline $\begin{array}{c}\text { Bellidea } \\
(2017-2018) \text { [19] }\end{array}$ & Switzerland & $\mathrm{APP}$ & Citizens & $\begin{array}{l}\text { Track users' } \\
\text { routes and } \\
\text { give feedback } \\
\text { on how and } \\
\text { how much } \\
\text { they move } \\
\text { Provide } \\
\text { points, de- } \\
\text { pending on } \\
\text { how users } \\
\text { move and } \\
\text { which means } \\
\text { of transport } \\
\text { they use. } \\
\text { Points can } \\
\text { be redeemed } \\
\text { for real-life } \\
\text { prizes }\end{array}$ & $\begin{array}{l}\text { - } 600 \text { citizens regis- } \\
\text { tered on the app } \\
\text { Around } 180 \text { of } \\
\text { them regularly } \\
\text { used it for at least } \\
6 \text { weeks each. }\end{array}$ \\
\hline
\end{tabular}


Table 1. Cont.

\begin{tabular}{|c|c|c|c|c|c|}
\hline Project (Year) & Where & Type & Who & How & Results \\
\hline \multicolumn{6}{|c|}{ Energy efficiency in buildings } \\
\hline $\begin{array}{c}\text { Charged } \\
(2016-2019) \text { [22] }\end{array}$ & $\begin{array}{l}\text { Luxembourg, } \\
\text { Spain, Greece }\end{array}$ & APP & Public buildings & $\begin{array}{l}\text { Personalized } \\
\text { real-time } \\
\text { recommenda- } \\
\text { tions to each } \\
\text { individual } \\
\text { end-user } \\
12 \text { different } \\
\text { in-game chal- } \\
\text { lenges were } \\
\text { designed, } \\
\text { all linked } \\
\text { to different } \\
\text { user actions } \\
\text { that reduce } \\
\text { or time-shift } \\
\text { energy con- } \\
\text { sumption }\end{array}$ & $\begin{array}{l}\text { Users self- } \\
\text { reported } 2.44 \% \\
\text { improvement for } \\
\text { turning their PC } \\
\text { off after work } \\
\text { and } 3.46 \% \text { im- } \\
\text { provement for } \\
\text { turning off the } \\
\text { lights after work. } \\
\text { Self-reported } \\
\text { energy-saving } \\
\text { behaviour at } \\
\text { work improved } \\
\text { by } 9.61 \% \text {. } \\
\text { The intention to } \\
\text { save energy im- } \\
\text { proved by } 2.82 \% \\
\text { Users ChArGED } \\
\text { game app sat- } \\
\text { isfaction was } \\
5.68 / 7 \text { and } 4.69 / 7 \\
\text { enjoyment in } \\
\text { both pilot sites }\end{array}$ \\
\hline $\begin{array}{l}\text { ENCOMPASS } \\
(2016-2019) \text { [20] }\end{array}$ & $\begin{array}{l}\text { Germany, Greece, } \\
\text { Switzerland }\end{array}$ & $\mathrm{APP}$ & $\begin{array}{c}\text { Residential, } \\
\text { Public building, } \\
\text { School }\end{array}$ & $\begin{array}{l}\text { Motivate } \\
\text { behavioural } \\
\text { changes com- } \\
\text { bining team } \\
\text { competition, } \\
\text { virtual re- } \\
\text { wards and } \\
\text { life simula- } \\
\text { tion }\end{array}$ & $\begin{array}{l}\text { - First results: } 10 \text { to } \\
12 \% \text { consumption } \\
\text { reduction for } \\
\text { the residential } \\
\text { consumers }\end{array}$ \\
\hline $\begin{array}{c}\text { FEEdBACk } \\
(2017-2021) \text { [23] }\end{array}$ & $\begin{array}{l}\text { Portugal, Spain, } \\
\text { Germany, } \\
\text { Holland, } \\
\text { Switzerland and } \\
\text { Denmark. }\end{array}$ & $\mathrm{APP}$ & $\begin{array}{l}\text { Public, services, } \\
\text { residential } \\
\text { buildings }\end{array}$ & $\begin{array}{l}\text { - Informative } \\
\text { videos and } \\
\text { episodes } \\
\text { on lighting, } \\
\text { heating or } \\
\text { appliances } \\
\text { Surveys on } \\
\text { day-to-day } \\
\text { decision- } \\
\text { making } \\
\text { regarding } \\
\text { energy- } \\
\text { efficient } \\
\text { behaviours }\end{array}$ & - $\quad$ Ongoing \\
\hline
\end{tabular}


Table 1. Cont.

\begin{tabular}{|c|c|c|c|c|c|}
\hline Project (Year) & Where & Type & Who & How & Results \\
\hline \multicolumn{6}{|c|}{ Sustainability awareness } \\
\hline $\begin{array}{c}\text { GAIA } \\
(2016-2019)[21]\end{array}$ & $\begin{array}{l}\text { Greece, Italy, } \\
\text { Sweden }\end{array}$ & Platform & Schools & $\begin{array}{l}\text { - Real-time } \\
\text { data from } \\
\text { sensors in the } \\
\text { buildings and } \\
\text { participatory } \\
\text { sensing help } \\
\text { to visualise } \\
\text { the real-life } \\
\text { impact of } \\
\text { students' } \\
\text { behaviour } \\
\text { and enable } \\
\text { competitive } \\
\text { gamification }\end{array}$ & $\begin{array}{l}\text { Over } 3000 \text { stu- } \\
\text { dents and } 200 \\
\text { educators par- } \\
\text { ticipated } 75 \% \\
\text { of the students } \\
\text { responded that } \\
\text { GAIA had a } \\
\text { positive influence } \\
\text { on them Energy } \\
\text { savings between } \\
15-20 \% \text { were ob- } \\
\text { tained in several } \\
\text { schools. }\end{array}$ \\
\hline
\end{tabular}

Given the importance of user engagement on the successful deployment of several ICT towards improving cities sustainability and environmental impacts, it is, therefore, crucial to evaluate the role of behavior and culture in their success but also to take a bottom-up approach [24] by engaging citizens in the decision making and tasks design. However, changing their behaviors can be a slow process and technology can play an important role in developing new urban services that generate high-impact behavior change. Changing behavior can be achieved through learning; however, it is essential to provide people with the necessary tools to enable the practice of new strategies until these become definitive [25]. Positive feedback and reinforcement are probably the most powerful educational elements in driving behavior change. When people have access to the results of their actions, it has been shown that they are more likely to change their behavior over time [26].

This work explores the concept that citizens must be engaged by being part of the decision-making process, through an integrated approach where they participate in codesign sessions of innovative solutions, shared learning initiatives and, consequently, become generators of data and information that can be applied for the development of new policies and new technologies. Including people in the design process, planning and management of these solutions has been shown to improve acceptability and increase their use [13].

\section{Sharing Cities Program}

The H2020 Sharing Cities lighthouse program [27] aims to achieve wide-scale deployment of smart cities solutions, shifting the thinking to decarbonized and local renewables and making the active engagement of citizens a reality, demonstrating and assessing how the innovative use of technologies and new products can improve city life and the lives of its inhabitants, creating safer, cleaner, smarter and more social cities. Sharing Cities aims to adopt a more agile and collaborative smart cities market, improving the speed and scale at which new solutions and services are implemented. Sharing Cities has three demonstration districts in Lisbon, London and Milan in which replicable urban digital solutions and collaborative models have been deployed such as building retrofit, the introduction of shared electric mobility services, implementation of energy management systems, city sensors and smart lamp posts and an urban sharing platform through engaging with citizens. "Fellow" cities Bordeaux, Burgas and Warsaw will co-develop, validate, or implement the above solutions. The Lisbon partners include the Lisbon Municipality, Lisboa E-Nova, Universidade de Lisboa-Instituto Superior Técnico, EDP-D, EMEL, Reabilita, CEiiA and Altice Labs. 
As previously mentioned, Sharing Cities aims at improving urban mobility, energy efficiency in buildings and carbon emissions by successfully engaging citizens in the transformation of their living context and fostering local-level innovation. As such, one of the actions promoted within the program was to develop a shared service model, enabling the creation of new urban services and incentivizing behaviour change by valuing and rewarding positive behaviours and choices related to energy efficiency, mobility, building retrofit, combining physical and digital environments-Digital Social Market (DSM). This innovative approach benefits citizens and brings communities together, fostering closer relationships among all members: citizens, retailers, community.

\section{Digital Social Market-Sharing Lisboa}

The DSM was named Sharing Lisboa. It was developed taking into account the local context and urban challenges identified by citizens, placing their needs and perceptions first. It works as an exchange of goods and services, encouraging citizen engagement through the creation and availability of new services and business models potentially leading to meaningful behaviour change incorporating smart city initiatives. Sharing Lisboa is supported by a mobile application allowing the digital and physical interactions between users, services and service providers. The concept of DSM was developed in several steps in a co-creation environment which enabled developing its different components, leading to a set of services that aim to strengthen the relationship between citizen and city. Within the DSM, the citizen can voluntarily engage in the marketplace taking advantage of its services and making choices based on common causes, incentives and/or reward mechanisms (Figure 1).

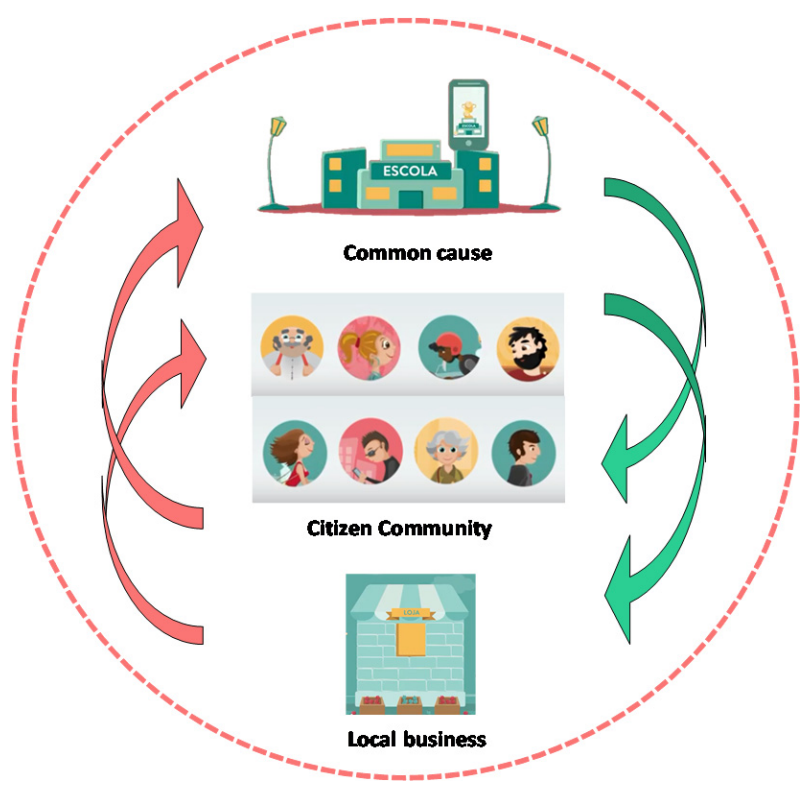

Figure 1. Digital Social Market structure.

\section{DSM Development}

Sharing Lisboa was developed with the guidance of Sharing Cities partner Future Cities Catapult and with the participation of Lisbon partners, over the course of two years, based in several stages considering a user research framework and design workshops involving city representatives, program partners and citizens. The User Research approach applies several methods based on observation, task analysis, among others [11], allowing to assess citizen's perceptions on the project's measures and if they respond adequately to their needs. These different stages included:

Step 1-Citizens needs identification

Step 2-Identification of features and motivations for engagement in the service 
Step 3-Co-creation sessions for DSM development

Step 4-Final DSM concept and operational features definition and implementation process

Step 5-Sharing Lisbon mobile application development

Step 6-Sharing Lisboa Pilot Launch

Step 7-Sharing Lisboa assessment

Step 1. Citizens' needs identification

In this stage, an initial questionnaire was used to recruit citizens to participate in the development of the concept. The selection of participants took into account a profile matrix that considered the type of transport used (private car, public, active and multimodal), energy awareness (high, medium and low), community involvement (high, medium and low) and digital use (super, high, medium, low). Both extreme and representative profiles were recruited. Of the 33 questionnaire survey responses, 11 participants ( 5 female and 6 male) were selected. Following this selection, the citizens were invited to volunteer in the construction of a Diary Study. This enabled the 11 participants to share in a blog their everyday behaviours, preferences and perspectives through the submission of photos, quotes, etc., related to four themes: daily routines, transportation, energy consumption and community life. An example of one blog entry is presented in Figure 2.

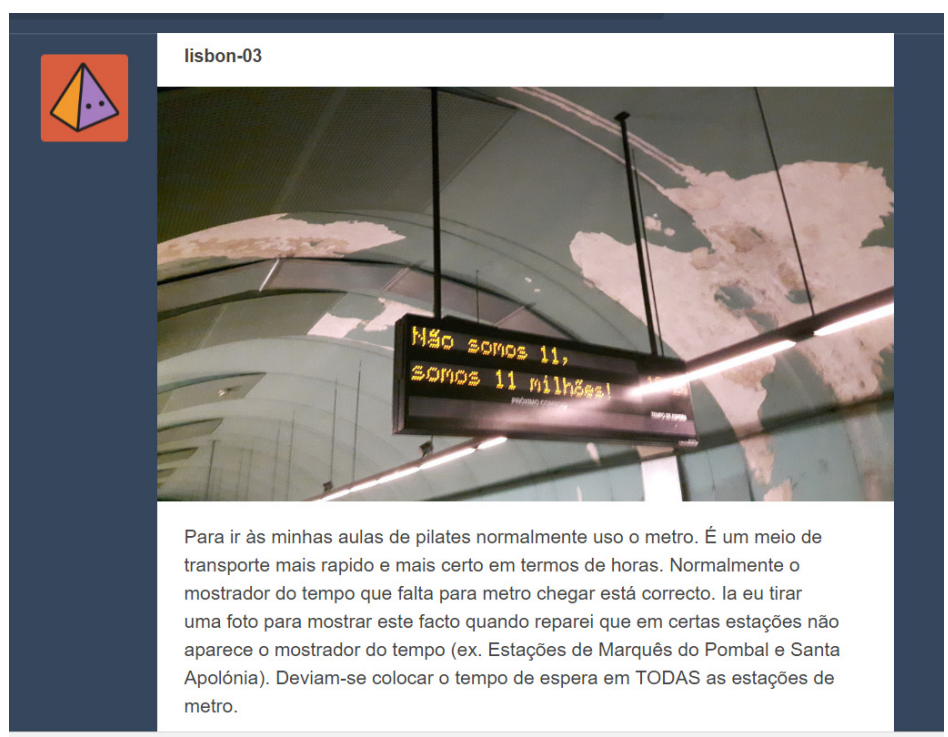

Figure 2. Example of diary study entry.

Step 2. Identification of features and motivations for engagement in the service

After the Diary Study period, 10 of the participants were then invited to participate in individual in-context interviews, to deepen and clarify their diary study contributions and to gain further knowledge on their routines, patterns, ideas, and willingness to accept future smart solutions implemented in the city and how they would respond to different incentives promoting the adoption of those solutions. Eight additional participants were recruited for the interviews covering missing profiles. A total of 18 interviews were conducted (11 female and 7 male) with an average duration of approximately 2 hours. The results allowed the creation of citizen profiles and categorization of data in several themes (as presented in Figure 3).

The next step was to promote meetings with city representatives and workshops with project partners in order to align the findings previously identified with the strategic priorities of the city of Lisbon and how to best build the DSM as a tool to achieve them. Besides city representatives and project partners, several stakeholders from the mobility and energy areas were also invited to participate. The final Lisbon goals identified can be seen in Figure 4. 


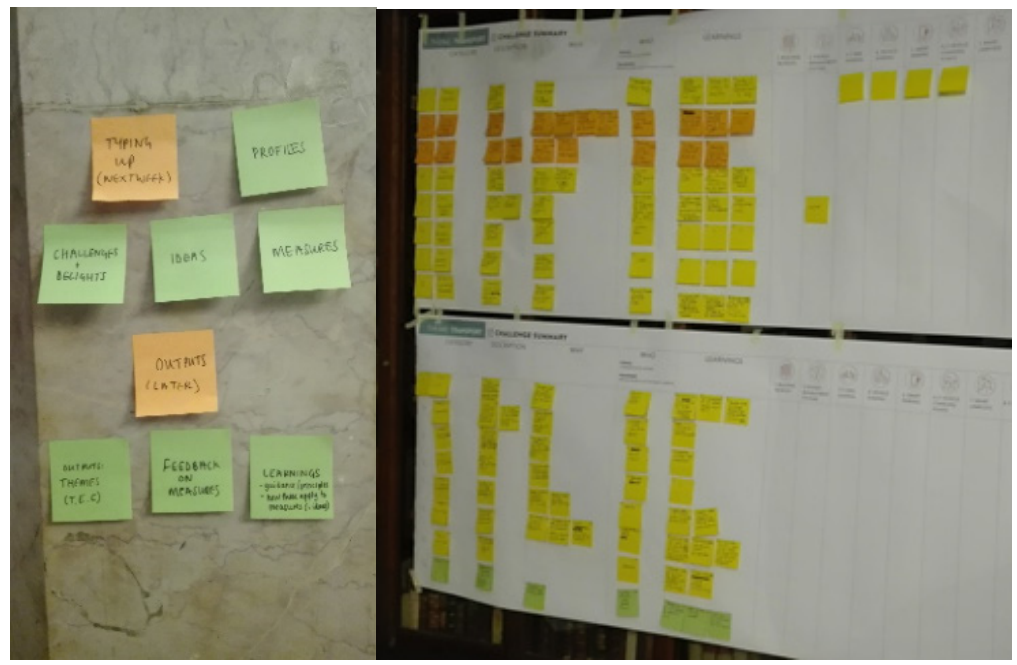

Figure 3. Organization of main findings from diary studies and interviews.

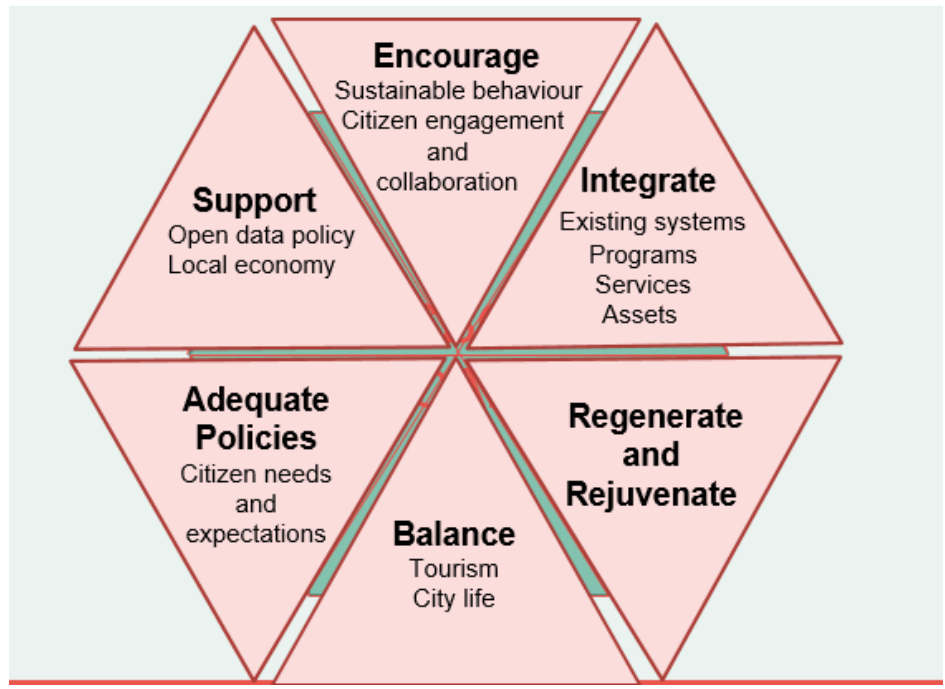

Figure 4. Identification of Lisbon goals.

Step 3. Co-creation sessions for DSM development

This stage contemplated workshops with Sharing Cities partners, in which the design and functioning of the DSM, and how it could be adapted to the Lisbon reality and available resources, were discussed. The main outputs of this workshop led to the first design of the DSM concept and user journey adapted to the Lisbon concept and how it could potentially work in the city.

With an initial DSM design and user journey created, the following activity required, once more, the participation of citizens in order to assess their willingness to adopt and use such a service, their perceptions towards the concept, challenges and expectations regarding DSM implementation in the city of Lisbon. For this, a total of three focus group sessions were conducted with a total of 14 citizens. Each session took between one and a half hours to two hours. Participants were recruited bearing in mind that they should reflect the demographics of the demonstration area (e.g., gender, age, employment status, etc.) but divided into heterogeneous groups to ensure a good mix of ideas and perspectives. Based on the information collected, it was possible to organize it into several categories: Dissemination and acceptance of DSM; DSM characteristics; Benefits for participants; and Common causes. Overall, the citizens had a positive acceptance of the DSM; however, it stood out that it was essential to show citizens its usefulness and the educational process 
to promote behaviour change and decision-making towards sustainability. A transversal theme that was raised in the focus groups was the citizens' desire to contribute to a cause through such a system and that schools could be the place to start implementing these types of services.

Step 4. Final DSM concept and operational features definition and implementation process

The steps following the Focus Group sessions were to, among the partners, develop the final concept, design and outline the implementation process. Within this stage, all the elements of the DSM were refined such as: main end-users, how to build and engage the community, how to incentive participation and promote behaviour change.

The final concept of Sharing Lisboa is translated into a platform that works as an exchange of goods and services, which will bring citizens together to support a common cause. Based on previous sessions conducted with citizens, a common cause was selected for which citizens could contribute through their participation and engagement. The common cause identified was the educational context with the participation of three schools that competed for the course of one academic year $(2018 / 2019)$ to win a final prize of EUR 20,000 to spend on energy-efficient measures to improve the school, the other two schools would win a participation prize of EUR 5000 each. Even though the DSM was mainly promoted in the competing schools, not only the school community was involved in it, but also the surrounding community, citizens and local business shops were incentivized to participate.

Three schools were selected taking into account Sharing cities demonstrating area (downtown Lisbon), schools that had no recent building improvements, students ages $\left(8^{\text {th }}\right.$ grade was considered as a target group due to energy efficiency and sustainability concepts being part of the curriculum) and schools located in three different parishes. As such the schools selected were: Escola Nuno Gonçalves, Penha de França; Escola Engenheiro Duarte Pacheco EB2+3, Olaias; and Escola Manuel da Maia, Campo de Ourique. Considering the three schools, a population of approximately 4500 students and 130,000 people from the three neighborhoods could be reached to participate in Sharing Lisboa. The selection of the schools took into consideration several aspects. The first one was that the schools were included in the demonstration area of the project, but in different parishes. Additionally, another aspect to take into consideration was to select schools that did not have any retrofit improvements that could improve the energy consumption of the school and, therefore, not allow a fair comparison of the schools' results. Elementary schools were excluded mainly due to the fact that, since DSM would mainly work through an APP, students would be required to use a smartphone to participate, and the team considered that students under the age of 10 do not own smartphones so the participation through the APP would only be targeted to adults, excluding the children. So the team then considered that secondary schools were the best group of students, aged between 10 and 15 years, to promote the DSM, particularly students from the $8^{\text {th }}$ grade (13-14 years old) whose educational curriculum starts to address themes such as climate change, energy efficiency, etc."

Sharing Lisboa aimed to create a sustainable community, promoting behaviour change and the adoption of more sustainable and efficient behaviours, such as: energy-saving behaviours, cycling, walking. Through the adoption of these behaviours, participants earn points that reverted to the cause (school) they supported. Participants could earn points from: walking; cycling; reducing energy consumption; charging an EV; checking-in at local shops; and filling thematic quizzes. Schools earned points by reducing energy consumption. Even though the points won by the participants reverted to the school they supported, after every 200 points won the participants would win a bonus. The bonus to the participants included discounts in the local business network that participated in the DSM. Participants received a voucher through the APP that they could redeem for a discount in one of the shops. They could choose in which shop to use the voucher.

Figure 5 presents the calculations considered for points attribution for each of the behaviours and services from which participants could benefit from. 


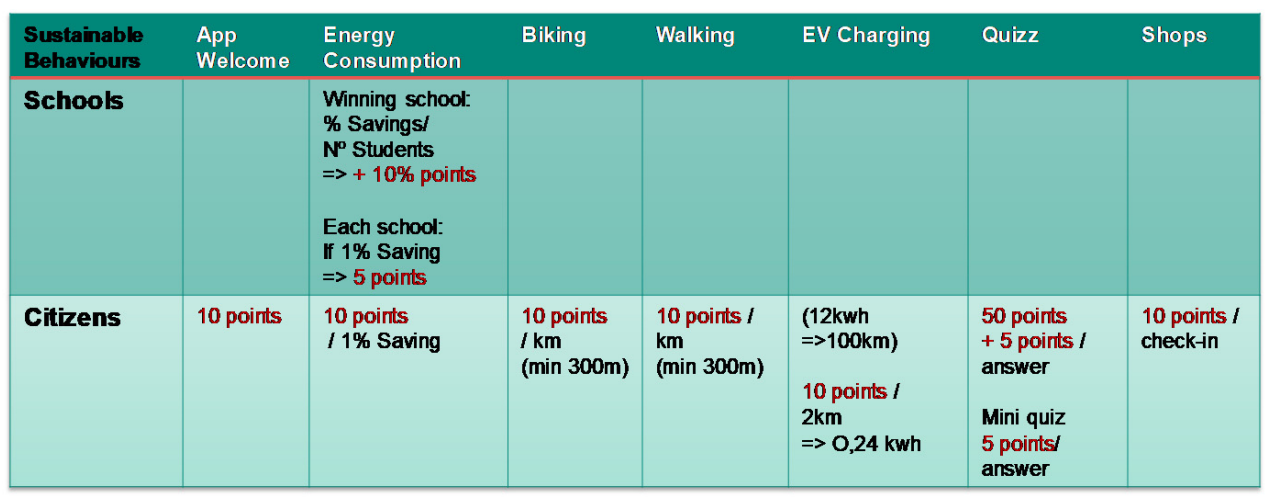

Figure 5. Sharing Lisboa rewards attribution.

Since the DSM was implemented in schools, in which several activities and awareness campaigns were promoted among students, teachers, workers and parents, there was a DSM agent totally dedicated to Sharing Lisboa during the development and implementation stages in order to motivate and engage participants. The Sharing Lisboa agent was responsible for promoting and organising meetings with schools' communities to launch the Sharing Lisboa pilot. A video presenting Sharing Lisboa and explaining how it worked was also made and showed in the schools to motivate participation. Furthermore, several Sharing Lisboa merchandise was produced, such as pencils, umbrellas, headphones, among other to offer the students, teachers and school staff to promote the DSM. Additionally, the agent not only developed activities and regular sessions focused on sustainability, energy efficiency and mobility; but was also periodically present in the three schools with the aim of supporting the community by assessing their perceptions towards the Sharing Lisboa, challenges with APP usage, new ideas proposals, changes needed, etc.

Furthermore, some activities were promoted within the APP throughout the year, like gaining double the points on a specific activity in a specific period (e.g., one week). Regarding users from outside the school community, such as the people living in the neighbourhood and local business stores, the video was used to promote the DSM and leaflets were distributed within the three neighbourhoods.

Furthermore, community interaction activities also took place, aiming for the creation of a local shops network with which the school and neighbourhood communities could interact. Participants were also motivated to propose the inclusion of new businesses.

Regarding users from outside the school community, such as the people living in the neighbourhood and local business stores, the video was used to promote the DSM and leaflets were distributed within the three neighbourhoods.

Step 5. Sharing Lisbon mobile application development

The Sharing Lisboa APP was also developed in the context of co-design using a designthinking methodology. Within the Lisbon' consortium, tacking in account all the feedbacks obtained by the involved community, AlticeLabs lead several sessions to collect all the uses cases and define the contents of the app. Beta-tester provided continuous feedback on the APP and its content and Lisbon team met regularly with the technical team to further discuss the app and suggest changes and improvements. Figure 6 presents how the Sharing Lisboa APP worked. An Android version of the APP was the first to be developed and was launched in November 2018. The IOS version was launched in the first trimester of 2019. 


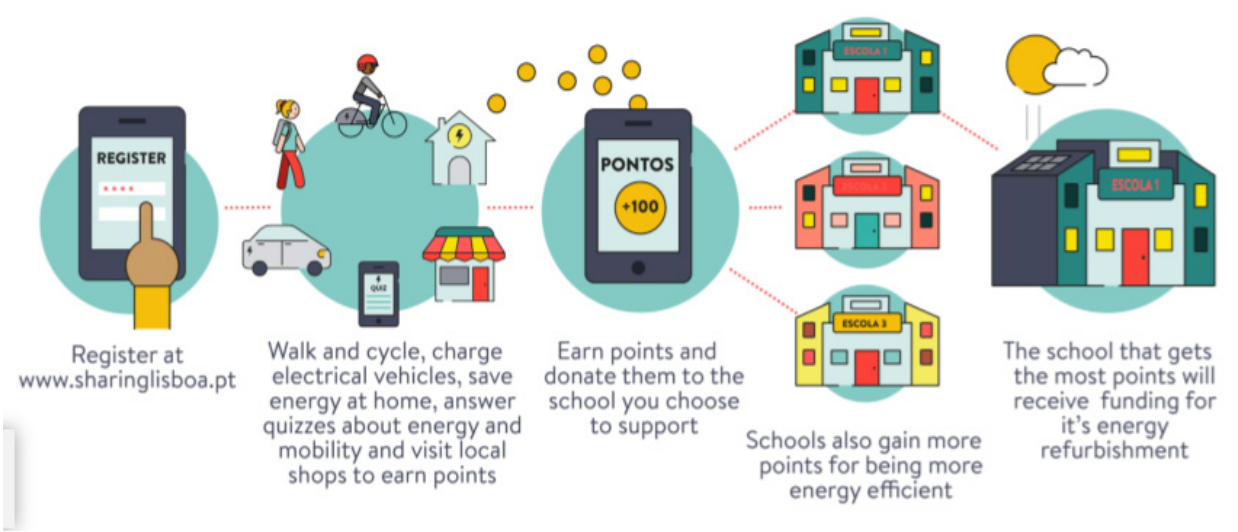

Figure 6. Sharing Lisboa: how does it work?

The Sharing Lisboa APP was composed of several components, that were developed with the team following the aims of Sharing Lisboa and the concept developed is presented in Figure 7:

- Integration with external accounts to monitor behaviours (Google Fit, Strava, EDP Distribuiçao, CEiiA);

- Participants history page to check progress, points and contributions;

- Common causes page to check schools progress, points and contributions; and

- Thematic quizzes (sustainable mobility and energy efficiency), used to educate and motivate participants to earn more points.

Step 6. Sharing Lisboa Pilot Launch

The Lisbon Digital Social Market—Sharing Lisboa pilot was launched in November 2018 working for a period of 6 months. During the duration of the Pilot, data were collected through monitoring of the Sharing Lisboa APP.

Step 7. Sharing Lisboa assessment

Data were collected on several indicators such as: number of new registrations, number of total transactions, points obtained, number of specific transactions (e.g., walking, quizzes, etc.), number of kilometers travelled through walking and cycling, number of check-ins performed and number of bonuses claimed. Due to data privacy constraints, it was not possible to collect information on the type of user (e.g., student, teacher, staff, parent, other), gender and age.

In order to assess the impacts of Sharing Lisboa on user behaviour, two questionnaires were conducted. One of the questionnaires aimed to assess energy and mobility patterns and changes in behaviour due to Sharing Lisboa. The second questionnaire was conducted to assess users Sharing Lisboa APP usage patterns (e.g., how many times per day they accessed the APP, average time per usage, etc.). Of the 1260 users, the return of both questionnaires was 3.17\% (40 answers) for the former and 1.03\% (13 answers) for the latter. Due to privacy issues, it is not possible to connect the answers with the user profile from the Sharing Lisboa APP, which would provide us with more information regarding APP usage patterns. 


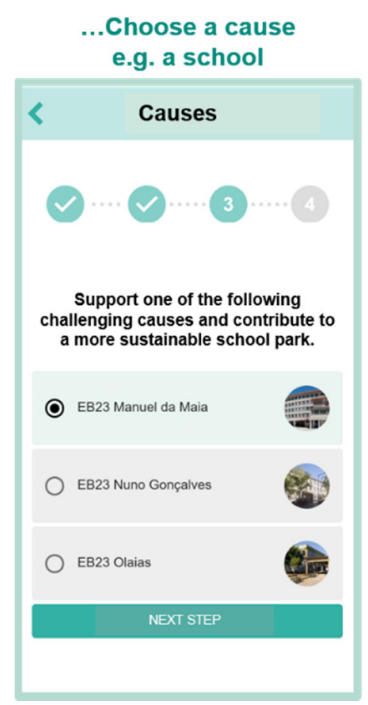

...earning points... by saving energy, walking...

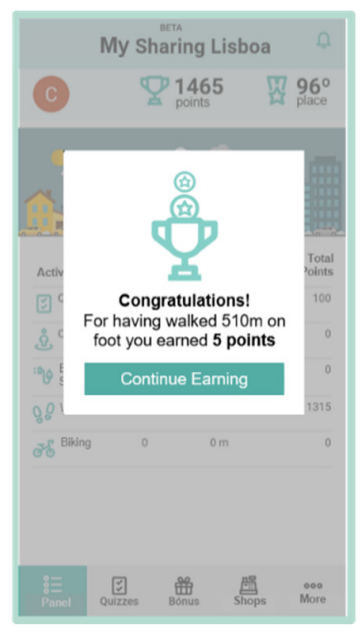

...Integrate with external existing accounts

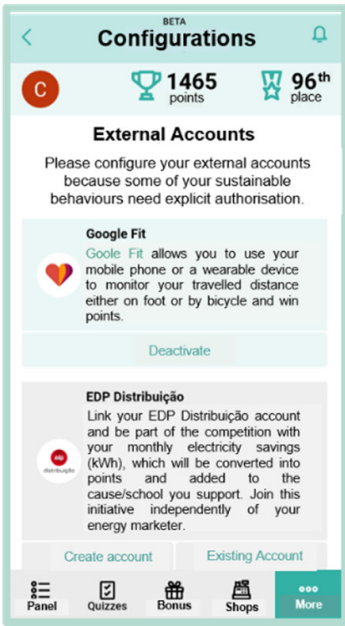

...earning points... by learning...

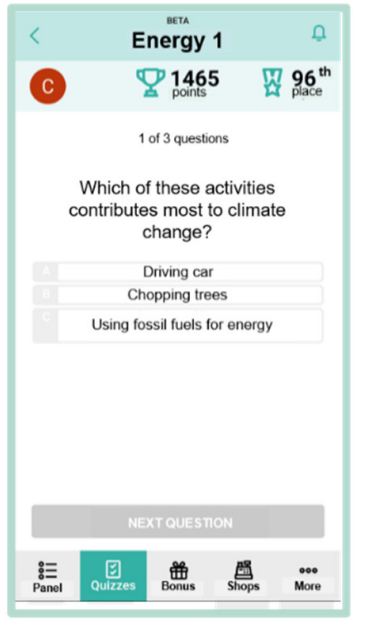

..Check personal contributions and progress

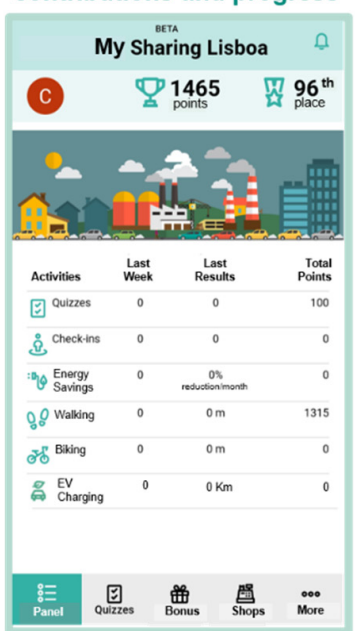

...earning points... by supporting local business!

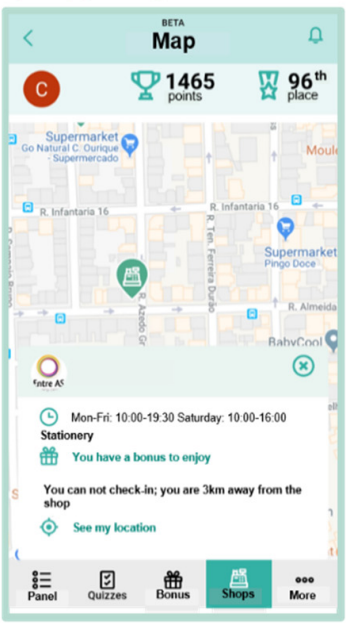

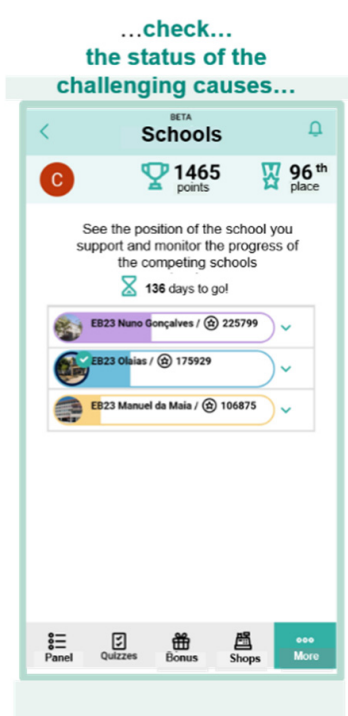

$$
\begin{aligned}
& \text { the status of the } \\
& \text { available bonus. } \\
& \text { Bonus } \\
& \text { C } 1465 \text { ponts } 96^{\text {th }} \\
& \begin{array}{l}
\text { Redeem your bonus credits. Check } \\
\text { out the bonuses available. }
\end{array}
\end{aligned}
$$

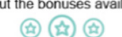

$$
\begin{aligned}
& 1465 \text { bonus credits. } \\
& \text { Closest Most Reachable } \\
& \begin{array}{ll}
\text { os mimos do } & 74 \\
\text { churrasco } & \text { m } \\
\text { Offer of on the } \\
\text { purchase of } 1 \text { roasted } \\
\text { chicken, offer } 1 \text { bag }
\end{array}
\end{aligned}
$$

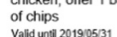

$$
\begin{aligned}
& \text { 17. } \\
& \text { dessert and coffee }
\end{aligned}
$$

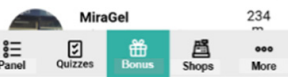

Figure 7. Sharing Lisboa APP screens. 


\section{Sharing Lisboa Results}

Over the 6 months during which Sharing Lisboa operated, a total of 1260 users registered in the Sharing Lisboa APP, collecting more than 850,000 points through a total of approximately 17,000 transactions done in the APP, can be seen in Table 2. Among these transactions, it is possible to ascertain that the higher number of transactions was collected through filling the thematic quizzes, with approximately 7500 transactions, followed by check-in at local shops, walking and cycling. Regarding walking and cycling distance, more than $16000 \mathrm{~km}$ were travelled within the Sharing Lisboa community. A total of 258 bonus were claimed in the local shops network over the 6 months.

Table 2. Sharing Lisboa indicators.

\begin{tabular}{|c|c|c|c|c|c|c|c|c|c|}
\hline \multirow{2}{*}{ Schools } & \multicolumn{9}{|c|}{ Sharing Lisboa } \\
\hline & Users & Points & Transactions & $\begin{array}{l}\text { Walking } \\
\text { Transaction }\end{array}$ & $\begin{array}{c}\text { Cycling } \\
\text { Transaction }\end{array}$ & $\begin{array}{c}\text { Quizz } \\
\text { Transaction }\end{array}$ & Check-in & $\begin{array}{l}\text { Walking } \\
\text { Distance }\end{array}$ & $\begin{array}{l}\text { Cycling } \\
\text { Distance }\end{array}$ \\
\hline $\begin{array}{c}\text { Nuno } \\
\text { Gonçalves }\end{array}$ & 632 & 487,599 & 11,999 & 2486 & 99 & 4490 & 4292 & 10,468 & 584 \\
\hline Olaias & 372 & 238,642 & 3010 & 674 & 25 & 1848 & 91 & 2916 & 70 \\
\hline $\begin{array}{l}\text { Manuel } \\
\text { da Maia }\end{array}$ & 256 & 141,495 & 2209 & 606 & 37 & 1121 & 445 & 1888 & 136 \\
\hline Total & 1260 & 867,736 & 17,218 & 3766 & 161 & 7459 & 4828 & 15,272 & 790 \\
\hline
\end{tabular}

Regarding evolution over time and differences between schools, it is possible to see from the following figures (Figures 8-10) that the number of participants, transactions and points increased through the 6 months implementation period in a consistent way, with an average of $119 \%$ increase per month. Additionally, Nuno Gonçalves School always presented higher numbers than the two other schools.

Similar patterns were observed for the different transactions: quizzes, check-in, walking and cycling, as presented in Figures 11-14.

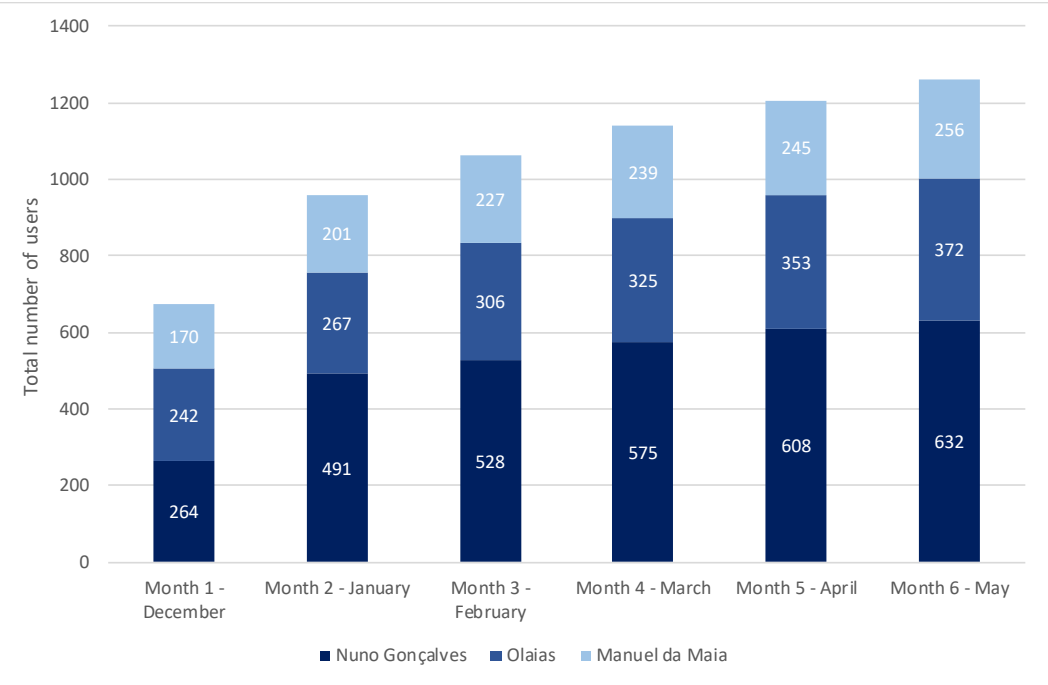

Figure 8. Evolution of total number of users per school and over time. 


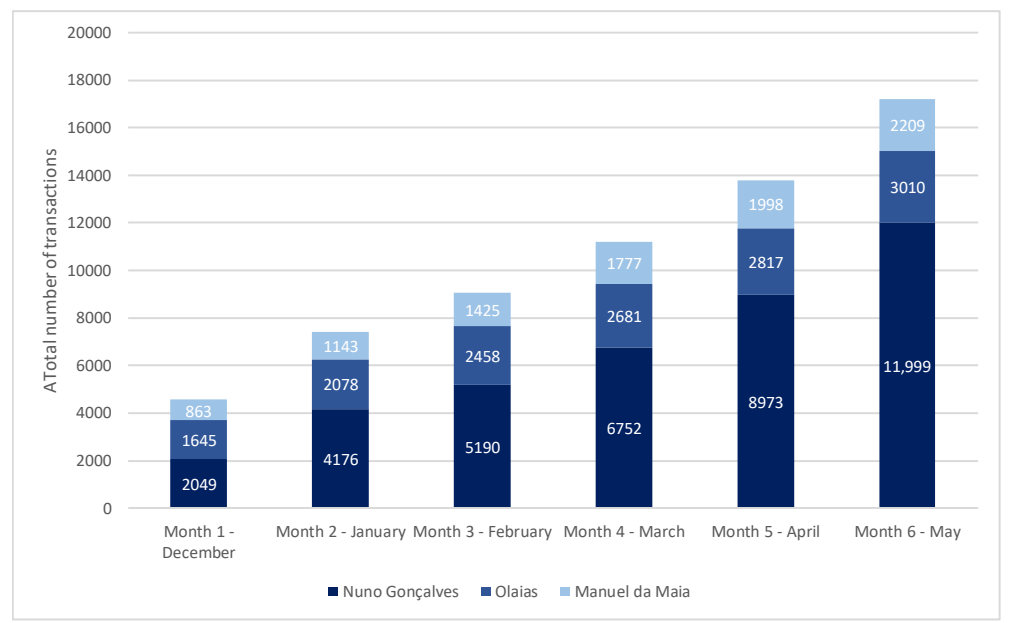

Figure 9. Evolution of total number of transactions per school and over time.

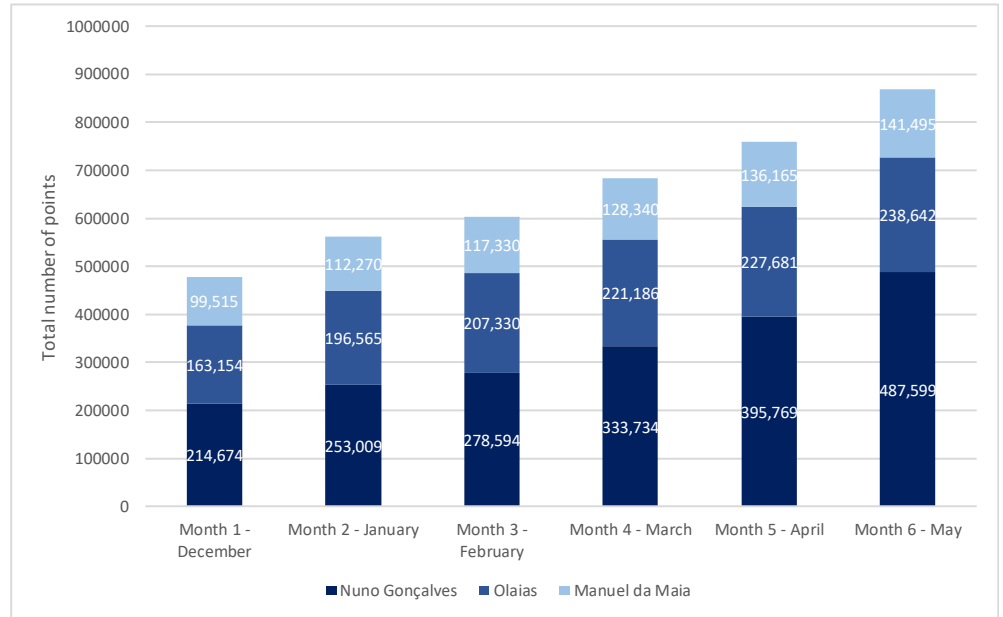

Figure 10. Evolution of total number of points per school and over time.

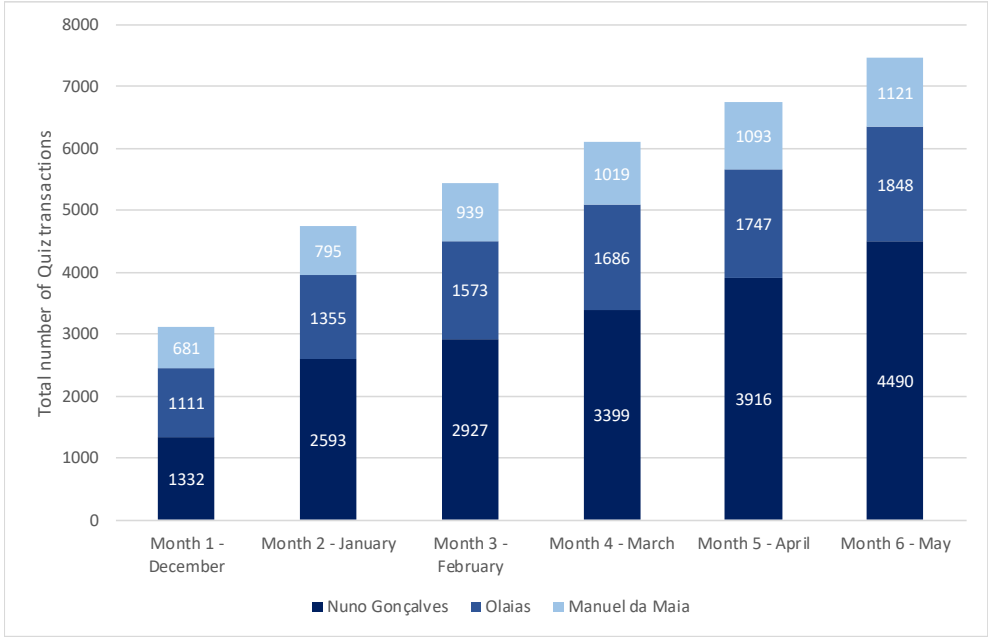

Figure 11. Evolution of total number of quiz transactions per school and over time. 


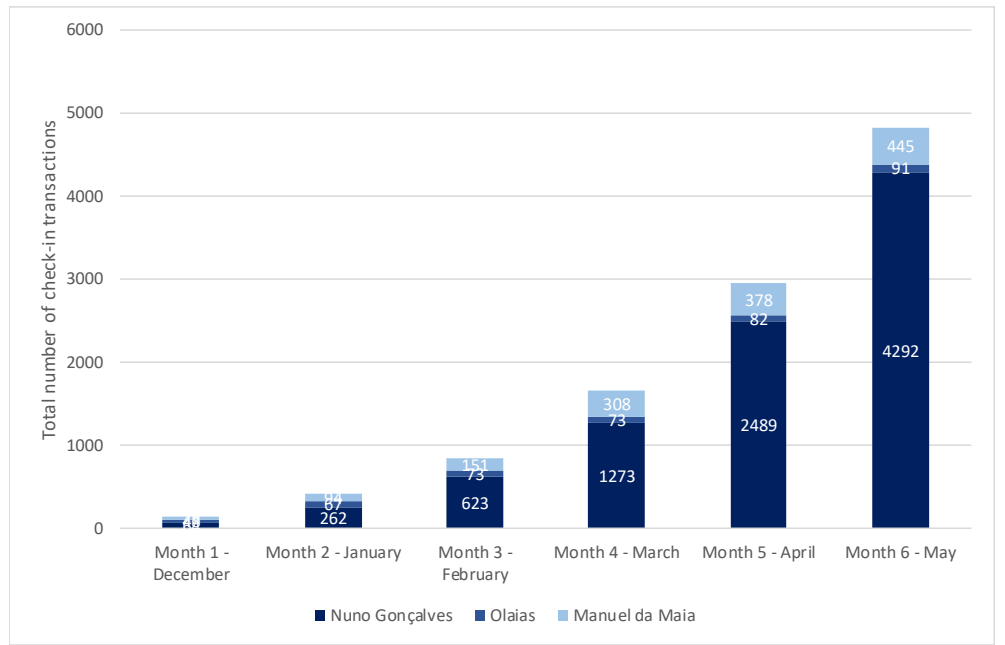

Figure 12. Evolution of total number of check-in transactions per school and over time.

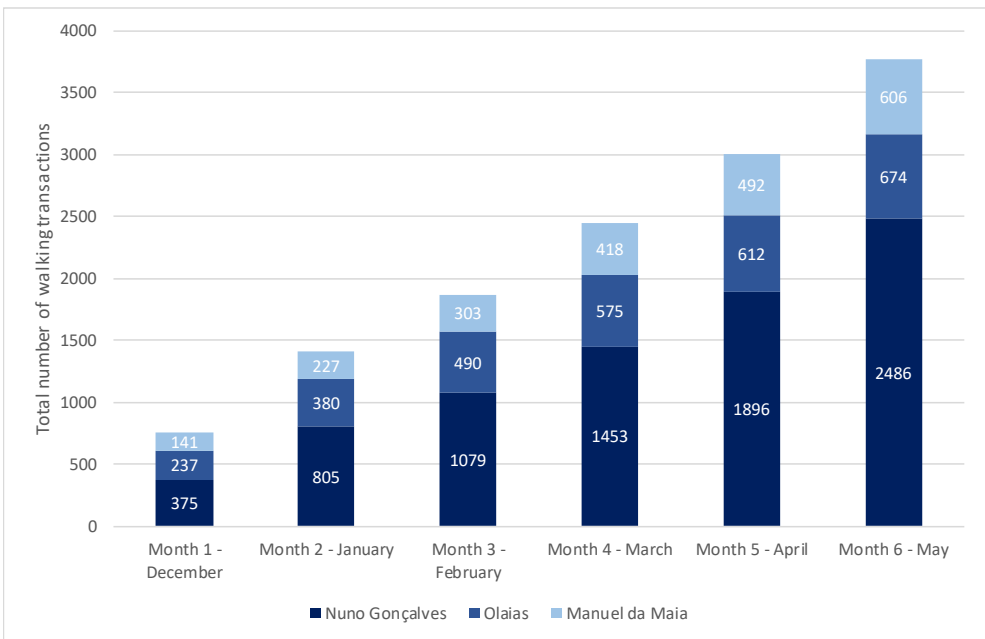

Figure 13. Evolution of total number of walking transactions per school and over time.

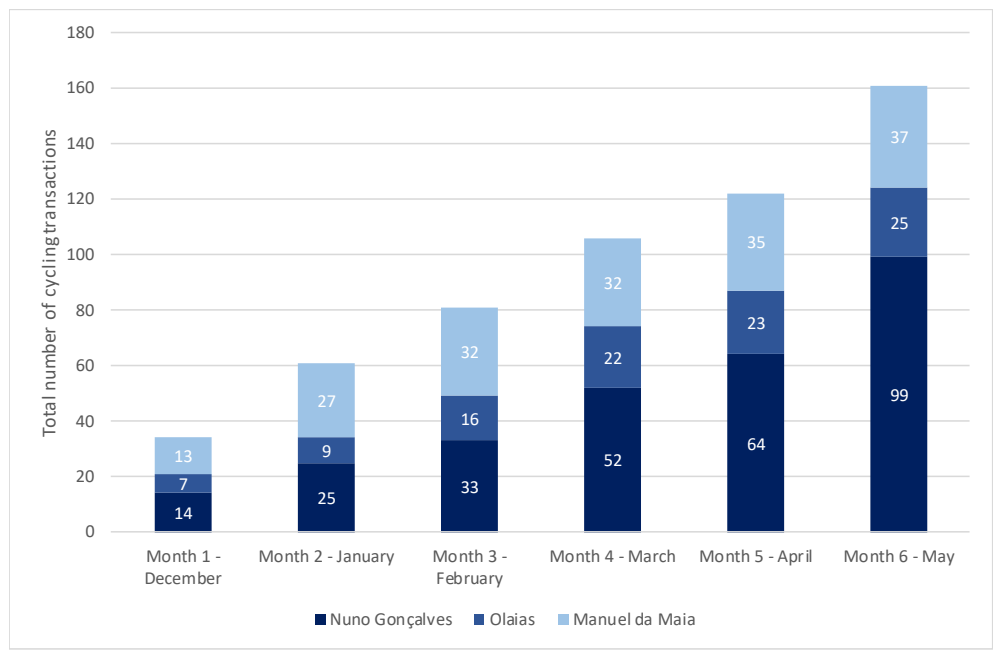

Figure 14. Evolution of total number of cycling transactions per school and over time.

Figures 15 and 16 present the evolution of the kilometers travelled walking and cycling, with data revealing an increase in kilometers over the last months of the pilot 
implementation, particularly in what concerns cycling, which might be explained due to improvement in weather conditions.

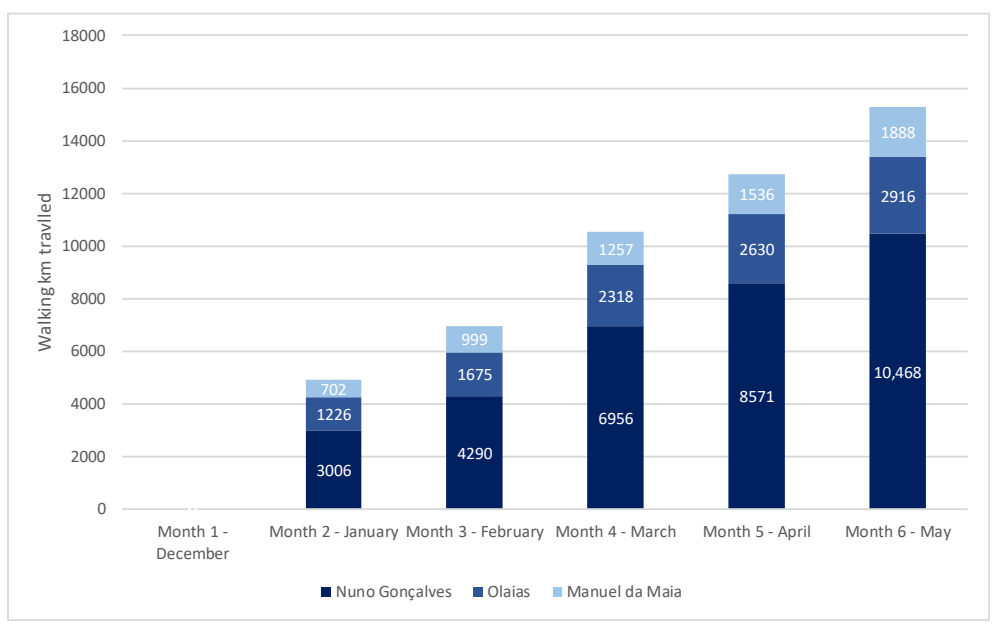

Figure 15. Evolution of total number of $\mathrm{km}$ travelled walking per school and over time.

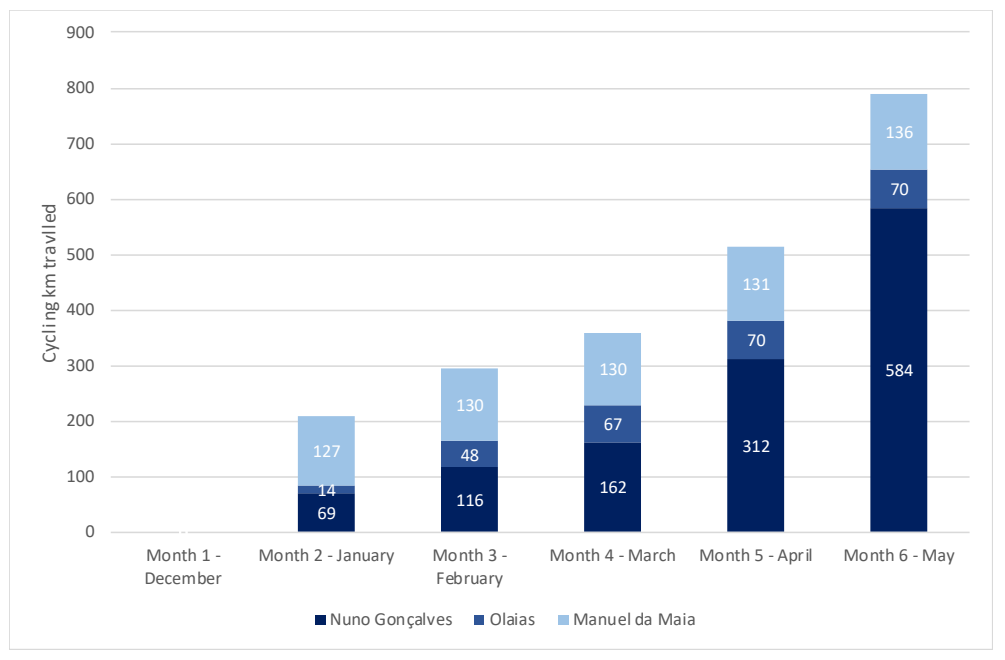

Figure 16. Evolution of total number of $\mathrm{km}$ travelled cycling per school and over time.

\section{Impacts on User Behaviour and Sharing Lisboa Usage Patterns}

\subsection{Impacts on User Behaviour}

As previously mentioned, 40 answers were obtained from the questionnaire to assess energy and mobility patterns and changes in behaviour due to Sharing Lisboa. A majority, $45 \%$, of the respondents were school staff (teachers and staff), followed by parents (23\%), neighbourhood residents (15\%). Regarding students, only three students filled the questionnaire. Regarding age, $58 \%$ of the respondents are between 36 and 55 years, with $8 \%$ being younger than 18 years representing the students. Furthermore, $65 \%$ of the respondents were female and $35 \%$ male.

When questioned about their concern regarding their energy consumption at home, the majority of the respondents revealed they are extremely concerned, as can be seen in Table 3. While $97 \%$ of the respondents indicated they knew how much they spent in Euros per month on energy, only $57 \%$ indicated they knew what that represented in $\mathrm{kWh}$. 
Table 3. Level of concern with energy consumption at home according to type of use.

\begin{tabular}{ccccccccccc}
\hline $\begin{array}{c}\text { Level of Concern } \\
\begin{array}{c}\text { Regarding Energy } \\
\text { Consumption at Hom }\end{array}\end{array}$ & \multicolumn{2}{l}{ Parents } & School Staff & \multicolumn{2}{c}{$\begin{array}{c}\text { Neighb. } \\
\text { Resident }\end{array}$} & & Other & Total \\
\hline 1 (not concerned) & 0 & $0 \%$ & 0 & $0 \%$ & 0 & $0 \%$ & 0 & $0 \%$ & 0 & $0 \%$ \\
\hline 2 & 0 & $0 \%$ & 0 & $0 \%$ & 0 & $0 \%$ & 0 & $0 \%$ & 0 & $0 \%$ \\
\hline 3 & 1 & $11 \%$ & 0 & $0 \%$ & 0 & $0 \%$ & 0 & $0 \%$ & 1 & $3 \%$ \\
\hline 4 & 4 & $44 \%$ & 4 & $22 \%$ & 3 & $50 \%$ & 3 & $50 \%$ & 14 & $38 \%$ \\
\hline 5 (extremely concerned) & 4 & $44 \%$ & 14 & $78 \%$ & 3 & $50 \%$ & 1 & $17 \%$ & 22 & $59 \%$ \\
\hline Total & 9 & $100 \%$ & 18 & $100 \%$ & 6 & $100 \%$ & 4 & $67 \%$ & 37 & $100 \%$ \\
\hline
\end{tabular}

All students indicated they considered that saving energy is important, while $70 \%$ of the respondents indicated that they consider it is extremely important to save energy, particularly school staff, as can be seen in Table 4 . The main reason for this is related to: contributing to a more sustainable environment $(29 \%)$ and saving the planet resources $(27 \%)$, followed by reducing bills and decreasing $\mathrm{CO}_{2}$ emissions, as can be seen in Table 5 .

Table 4. Importance level attributed to saving energy according to type of user.

\begin{tabular}{ccccccccccc}
\hline $\begin{array}{c}\text { Importance Level } \\
\begin{array}{c}\text { Attributed to Energy } \\
\text { Saving }\end{array}\end{array}$ & \multicolumn{2}{l}{ Parents } & School Staff & \multicolumn{2}{c}{$\begin{array}{c}\text { Neighb. } \\
\text { Resident }\end{array}$} & & Other & Total \\
\hline Not important & 0 & $0 \%$ & 0 & $0 \%$ & 0 & $0 \%$ & 0 & $0 \%$ & 0 & $0 \%$ \\
\hline Low importance & 0 & $0 \%$ & 0 & $0 \%$ & 0 & $0 \%$ & 0 & $0 \%$ & 0 & $0 \%$ \\
\hline Important & 1 & $13 \%$ & 0 & $0 \%$ & 0 & $0 \%$ & 0 & $0 \%$ & 1 & $3 \%$ \\
\hline Very important & 3 & $38 \%$ & 4 & $22 \%$ & 2 & $33 \%$ & 1 & $25 \%$ & 10 & $27 \%$ \\
\hline Extremely important & 5 & $63 \%$ & 14 & $78 \%$ & 4 & $67 \%$ & 3 & $75 \%$ & 26 & $70 \%$ \\
\hline Total & 8 & $100 \%$ & 18 & $100 \%$ & 6 & $100 \%$ & 4 & $100 \%$ & 37 & $100 \%$ \\
\hline
\end{tabular}

Table 5. Reasons for saving energy according to type of user.

\begin{tabular}{|c|c|c|c|c|c|c|c|c|c|c|}
\hline \multirow{2}{*}{$\begin{array}{c}\text { Why do Think It Is } \\
\text { Important to Save Energy }\end{array}$} & \multicolumn{2}{|c|}{ Parents } & \multicolumn{2}{|c|}{ School Staff } & \multicolumn{2}{|c|}{$\begin{array}{l}\text { Neighb. } \\
\text { Resident }\end{array}$} & \multicolumn{2}{|c|}{ Other } & \multicolumn{2}{|c|}{ Total } \\
\hline & 9 & $30 \%$ & 14 & $26 \%$ & 6 & $32 \%$ & 4 & $33 \%$ & 33 & $29 \%$ \\
\hline Save planet resources & 7 & $23 \%$ & 17 & $31 \%$ & 4 & $21 \%$ & 4 & $33 \%$ & 32 & $28 \%$ \\
\hline Reduce bills (EUR/year) & 7 & $23 \%$ & 13 & $24 \%$ & 5 & $26 \%$ & 2 & $17 \%$ & 27 & $23 \%$ \\
\hline Decrease $\mathrm{CO}_{2}$ emissions & 7 & $23 \%$ & 10 & $19 \%$ & 4 & $21 \%$ & 2 & $17 \%$ & 23 & $20 \%$ \\
\hline Total & 30 & $100 \%$ & 54 & $100 \%$ & 19 & $100 \%$ & 12 & $100 \%$ & 115 & $100 \%$ \\
\hline
\end{tabular}

Students revealed they already had knowledge on most energy-saving behaviours presented to them, with the exception of changing light bulbs for more efficient ones, choosing new appliances according to energy efficiency evaluation and using eco-programs with washing machine and dishwasher (Table 6).

As for the main transport mode used daily, walking is the main mobility option used by $53 \%$, followed by private car $(18 \%)$, as can be seen in Table 7 . The main motives to use main transport mode is because it is easy $(81 \%)$, it is good for the health $(57 \%)$ and it is good for the environment (54\%), as can be seen in Table 8 . 
Table 6. Students' knowledge of energy-saving behaviours.

\begin{tabular}{|c|c|c|c|c|}
\hline \multirow{2}{*}{$\begin{array}{c}\text { Student's Knowledge of Energy-Saving Behaviours } \\
\text { Turn off the lights when leaving a room }\end{array}$} & \multicolumn{2}{|c|}{ I Know } & \multicolumn{2}{|c|}{ I Do Not Know } \\
\hline & 3 & $100 \%$ & 0 & $0 \%$ \\
\hline Only use the washing machine/dishwasher when in full capacity & 3 & $100 \%$ & 0 & $0 \%$ \\
\hline Change old lamp bulbs for more efficient ones (e.g., LED) & 2 & $67 \%$ & 1 & $33 \%$ \\
\hline Always turn off electronic devices (e.g., tv) from the plug & 3 & $100 \%$ & 0 & $0 \%$ \\
\hline Always turn off appliances (e.g., dishwasher) from the plug & 3 & $100 \%$ & 0 & $0 \%$ \\
\hline Always choose new appliances in accordance with energetic evaluation & 2 & $67 \%$ & 1 & $33 \%$ \\
\hline Do not leave the phone charger plugged & 3 & $100 \%$ & 0 & $0 \%$ \\
\hline $\begin{array}{c}\text { Change a non-efficient appliance, device or equipment with a more } \\
\text { efficient one }\end{array}$ & 3 & $100 \%$ & 0 & $0 \%$ \\
\hline Only use eco programs to wash clothes and dishes & 2 & $67 \%$ & 1 & $33 \%$ \\
\hline
\end{tabular}

Table 7. Main transport mode used according to type of user.

\begin{tabular}{cccccccccccccc}
\hline $\begin{array}{c}\text { Main Transport } \\
\text { Mode }\end{array}$ & \multicolumn{2}{l}{ Students } & \multicolumn{2}{c}{ Parents } & \multicolumn{2}{c}{ School Staff } & \multicolumn{2}{c}{$\begin{array}{c}\text { Neighb. } \\
\text { Resident }\end{array}$} & Other & Total \\
\hline Walking & 1 & $33 \%$ & 4 & $44 \%$ & 11 & $61 \%$ & 4 & $67 \%$ & 1 & $25 \%$ & 21 & $53 \%$ \\
\hline Bus & 1 & $33 \%$ & 0 & $0 \%$ & 0 & $0 \%$ & 1 & $17 \%$ & 0 & $0 \%$ & 2 & $5 \%$ \\
\hline Bike & 0 & $0 \%$ & 2 & $22 \%$ & 0 & $0 \%$ & 0 & $0 \%$ & 0 & $0 \%$ & 2 & $5 \%$ \\
\hline Car & 1 & $33 \%$ & 1 & $11 \%$ & 4 & $22 \%$ & 0 & $0 \%$ & 1 & $25 \%$ & 7 & $18 \%$ \\
\hline Subway & 0 & $0 \%$ & 1 & $11 \%$ & 0 & $0 \%$ & 0 & $0 \%$ & 1 & $25 \%$ & 2 & $5 \%$ \\
\hline Motorcycle & 0 & $0 \%$ & 1 & $11 \%$ & 0 & $0 \%$ & 0 & $0 \%$ & 0 & $0 \%$ & 1 & $3 \%$ \\
\hline Train & 0 & $0 \%$ & 0 & $0 \%$ & 3 & $17 \%$ & 0 & $0 \%$ & 0 & $0 \%$ & 3 & $8 \%$ \\
\hline Other & 0 & $0 \%$ & 0 & $0 \%$ & 0 & $0 \%$ & 1 & $17 \%$ & 1 & $25 \%$ & 2 & $5 \%$ \\
\hline Total & 3 & $100 \%$ & 9 & $100 \%$ & 18 & $100 \%$ & 6 & $100 \%$ & 4 & $100 \%$ & 40 & $100 \%$ \\
\hline
\end{tabular}

Table 8. Main reasons for using main transportation mode according to type of user.

\begin{tabular}{|c|c|c|c|c|c|c|c|c|c|c|}
\hline \multirow{2}{*}{$\begin{array}{c}\text { Why Do You Use This Mode of Transportation } \\
\text { It is good for my health }\end{array}$} & \multicolumn{2}{|c|}{ Parents } & \multicolumn{2}{|c|}{ School Staff } & \multicolumn{2}{|c|}{$\begin{array}{l}\text { Neighb. } \\
\text { Resident }\end{array}$} & \multicolumn{2}{|c|}{ Other } & \multicolumn{2}{|c|}{ Total } \\
\hline & 4 & $44 \%$ & 10 & $56 \%$ & 4 & $67 \%$ & 3 & $75 \%$ & 21 & $57 \%$ \\
\hline It is good for the environment & 6 & $67 \%$ & 9 & $50 \%$ & 3 & $50 \%$ & 2 & $50 \%$ & 20 & $54 \%$ \\
\hline It is easy to move this way & 6 & $67 \%$ & 16 & $89 \%$ & 5 & $83 \%$ & 3 & $75 \%$ & 30 & $81 \%$ \\
\hline I like to use this transportation mode & 6 & $67 \%$ & 4 & $22 \%$ & 3 & $50 \%$ & 0 & $0 \%$ & 13 & $35 \%$ \\
\hline It is the cheapest & 3 & $33 \%$ & 8 & $44 \%$ & 2 & $33 \%$ & 2 & $50 \%$ & 15 & $41 \%$ \\
\hline I have free parking & 1 & $11 \%$ & 0 & $0 \%$ & 0 & $0 \%$ & 0 & $0 \%$ & 1 & $3 \%$ \\
\hline It is the fastest & 1 & $11 \%$ & 4 & $22 \%$ & 3 & $50 \%$ & 2 & $50 \%$ & 10 & $27 \%$ \\
\hline It is the more flexible one & 2 & $22 \%$ & 1 & $6 \%$ & 1 & $17 \%$ & 0 & $0 \%$ & 4 & $11 \%$ \\
\hline It is the one that best fits the family routine & 2 & $22 \%$ & 2 & $11 \%$ & 1 & $17 \%$ & 0 & $0 \%$ & 5 & $14 \%$ \\
\hline The other transportation modes are not accessible & 0 & $0 \%$ & 1 & $6 \%$ & 0 & $0 \%$ & 1 & $25 \%$ & 2 & $5 \%$ \\
\hline Other: to be able to be on time & 1 & $11 \%$ & 0 & $0 \%$ & 0 & $0 \%$ & 0 & $0 \%$ & 1 & $3 \%$ \\
\hline $\begin{array}{c}\text { Other: I would like to use train but it does not } \\
\text { offer a quality service }\end{array}$ & 0 & $0 \%$ & 0 & $0 \%$ & 0 & $0 \%$ & 1 & $25 \%$ & 1 & $3 \%$ \\
\hline Total of respondents & 9 & - & 18 & - & 6 & - & 4 & - & 37 & - \\
\hline
\end{tabular}


Since using Sharing Lisboa APP, all students mentioned they started practicing behaviours to save energy. The same pattern is observed by parents $(78 \%)$ and by school staff, both at home and school (72\%). Half of those living in the neighbourhood revealed they did change their behaviours (Table 9). All students indicate they started plugging off electronic devices and two students indicated they no longer left the phone charger plugged, as can be seen in Table A1. Regarding school staff, both at home and school, $72 \%$ turn off the lights when leaving the room and $17 \%$ no longer leave their phone charger plugged in. Parents mentioned they changed a non-efficient device or appliance with a more efficient one $(85 \%)$, they started using eco programs and unplugging the phone charger $(71 \%)$, as seen in Table A1.

Table 9. Adoption of energy-saving behaviours after using Sharing Lisboa APP by type of user.

\begin{tabular}{|c|c|c|c|c|c|c|c|c|c|c|c|c|c|c|}
\hline \multirow{3}{*}{$\begin{array}{c}\text { Since You Started Using } \\
\text { Sharing Lisboa Have You } \\
\text { Started Practicing Any } \\
\text { Behaviour to Save Energy } \\
\text { No }\end{array}$} & \multirow{2}{*}{\multicolumn{2}{|c|}{$\begin{array}{l}\text { Students } \\
\text { At Home }\end{array}$}} & \multicolumn{6}{|c|}{ School Staff } & \multirow{2}{*}{\multicolumn{2}{|c|}{ Parents }} & \multirow{2}{*}{\multicolumn{2}{|c|}{$\begin{array}{l}\text { Neighb. } \\
\text { Resident }\end{array}$}} & \multirow{2}{*}{\multicolumn{2}{|c|}{ Other }} \\
\hline & & & \multicolumn{2}{|c|}{ At Home } & \multicolumn{2}{|c|}{ At School } & \multicolumn{2}{|c|}{$\begin{array}{c}\text { Home and } \\
\text { School }\end{array}$} & & & & & & \\
\hline & 0 & $0 \%$ & 3 & $17 \%$ & 1 & $6 \%$ & 1 & $6 \%$ & 1 & $11 \%$ & 3 & $50 \%$ & 1 & $25 \%$ \\
\hline I do not know & 0 & $0 \%$ & 0 & $0 \%$ & 0 & $0 \%$ & 0 & $0 \%$ & 1 & $11 \%$ & 0 & $0 \%$ & 1 & $25 \%$ \\
\hline Yes & 3 & $100 \%$ & 0 & $0 \%$ & 0 & $0 \%$ & 13 & $72 \%$ & 7 & $78 \%$ & 3 & $50 \%$ & 2 & $50 \%$ \\
\hline Total of respondentes & 3 & - & 18 & - & 18 & - & 18 & - & 9 & - & 6 & - & 4 & - \\
\hline
\end{tabular}

Using the Sharing Lisboa APP also led to some changes in the use of transport modes. For students, even though the use of most transport modes remained the same, one student indicated that the bus was more used, and that private car was used less. Regarding parents, these indicated that they started walking more (78\%) and have decreased the use of the private car $(56 \%)$ and bus ( $22 \%$ ), as can be seen in Table 10 . Of the school staff, $67 \%$ indicated they used the car less and 39\% indicated they used more public transportation (subway-39\% and bus-22\%). Neighborhood residents revealed they started walking more after starting to use the Sharing Lisboa APP (Table 10). When questioned about the reasons for changing behaviours (Table A2), users mentioned that they did so because they learned the importance of using energy in a more efficient way $(73 \%)$, of using less pollutant transport modes (55\%) and helping the school they supported (48\%). Of them, 30\% mention they changed behaviours to gain more points, while $13 \%$ did not change behaviours.

\subsection{Sharing Lisboa Usage Patterns}

As previously mentioned, the questionnaire related to the usage patterns of the Sharing Lisboa APP was answered by 13 users. While the number of responses is not representative, they can be indicative of some aspects of the APP usage, mainly related to access to the APP frequency and duration, which pages were visited, etc. No students filled the questionnaire and $38 \%$ were school staff. Furthermore, $62 \%$ were older than 46 years old, and $38 \%$ were aged between 26 and 45 years old and $54 \%$ were female.

The respondents knew about Sharing Lisboa through friends/colleagues (38\%), as seen in Table 11, and school activities were also the main modes of contact with Sharing Lisboa, either through the publicising panels (31\%) or through sessions conducted at the school $(23 \%)$. Helping the school win a reward was the main motive indicated to register in Sharing Lisboa, followed by the interest in learning about sustainable behaviours (37\%), as seen in Table 12. Furthermore, the majority of users reported they found it extremely easy to register in the APP (Table 13). 
Table 10. Transportation mode usage patterns after using Sharing Lisboa APP by type of user.

\begin{tabular}{|c|c|c|c|c|c|c|c|}
\hline \multicolumn{2}{|c|}{$\begin{array}{l}\text { After Using Sharing Lisboa Did the } \\
\text { Use of Transportation Mode Change }\end{array}$} & \multirow{2}{*}{$\begin{array}{c}\text { Car } \\
2\end{array}$} & \multirow{2}{*}{$\begin{array}{c}\text { Bus } \\
2 \\
\end{array}$} & \multirow{2}{*}{$\begin{array}{c}\text { Subway } \\
3\end{array}$} & \multirow{2}{*}{$\begin{array}{c}\text { Bike } \\
3 \\
\end{array}$} & \multirow{2}{*}{$\begin{array}{c}\text { Walking } \\
3 \\
\end{array}$} & \multirow{2}{*}{$\begin{array}{c}\text { Scooter } \\
2\end{array}$} \\
\hline \multirow{6}{*}{ Students } & \multirow{2}{*}{ Same } & & & & & & \\
\hline & & $67 \%$ & $67 \%$ & $100 \%$ & $100 \%$ & $100 \%$ & $67 \%$ \\
\hline & \multirow{2}{*}{ Less } & 1 & 0 & 0 & 0 & 0 & 0 \\
\hline & & $33 \%$ & $0 \%$ & $0 \%$ & $0 \%$ & $0 \%$ & $0 \%$ \\
\hline & \multirow{2}{*}{ More } & 0 & 1 & 0 & 0 & 0 & 0 \\
\hline & & $0 \%$ & $33 \%$ & $0 \%$ & $0 \%$ & $0 \%$ & $0 \%$ \\
\hline \multirow{6}{*}{ Parents } & \multirow{2}{*}{ Same } & 4 & 7 & 9 & 8 & 2 & 7 \\
\hline & & $44 \%$ & $78 \%$ & $100 \%$ & $89 \%$ & $22 \%$ & $78 \%$ \\
\hline & \multirow{2}{*}{ Less } & 5 & 2 & 0 & 0 & 0 & 1 \\
\hline & & $56 \%$ & $22 \%$ & $0 \%$ & $0 \%$ & $0 \%$ & $11 \%$ \\
\hline & \multirow{2}{*}{ More } & 0 & 0 & 0 & 1 & 7 & 1 \\
\hline & & $0 \%$ & $0 \%$ & $0 \%$ & $11 \%$ & $78 \%$ & $11 \%$ \\
\hline \multirow{6}{*}{ School staff } & \multirow{2}{*}{ Same } & 6 & 11 & 8 & 11 & 18 & 12 \\
\hline & & $33 \%$ & $61 \%$ & $44 \%$ & $61 \%$ & $100 \%$ & $67 \%$ \\
\hline & \multirow{2}{*}{ Less } & 12 & 3 & 3 & 3 & 0 & 6 \\
\hline & & $67 \%$ & $17 \%$ & $17 \%$ & $17 \%$ & $0 \%$ & $33 \%$ \\
\hline & \multirow{2}{*}{ More } & 0 & 4 & 7 & 4 & 0 & 0 \\
\hline & & $0 \%$ & $22 \%$ & $39 \%$ & $22 \%$ & $0 \%$ & $0 \%$ \\
\hline \multirow{6}{*}{ Neighb. resident } & \multirow{2}{*}{ Same } & 6 & 6 & 6 & 4 & 2 & 4 \\
\hline & & $100 \%$ & $100 \%$ & $100 \%$ & $67 \%$ & $33 \%$ & $67 \%$ \\
\hline & \multirow{2}{*}{ Less } & 0 & 0 & 0 & 2 & 0 & 2 \\
\hline & & $0 \%$ & $0 \%$ & $0 \%$ & $33 \%$ & $0 \%$ & $33 \%$ \\
\hline & \multirow{2}{*}{ More } & 0 & 0 & 0 & 0 & 4 & 0 \\
\hline & & $0 \%$ & $0 \%$ & $0 \%$ & $0 \%$ & $67 \%$ & $0 \%$ \\
\hline \multirow{6}{*}{ Other } & \multirow{2}{*}{ Same } & 3 & 4 & 3 & 2 & 1 & 2 \\
\hline & & $75 \%$ & $100 \%$ & $75 \%$ & $50 \%$ & $25 \%$ & $50 \%$ \\
\hline & \multirow{2}{*}{ Less } & 1 & 0 & 0 & 1 & 0 & 2 \\
\hline & & $25 \%$ & $0 \%$ & $0 \%$ & $25 \%$ & $0 \%$ & $50 \%$ \\
\hline & \multirow{2}{*}{ More } & 0 & 0 & 1 & 1 & 3 & 0 \\
\hline & & $0 \%$ & $0 \%$ & $25 \%$ & $25 \%$ & $75 \%$ & $0 \%$ \\
\hline
\end{tabular}

In what concerned frequency of use, $38 \%$ of the users indicate they accessed the APP at least once a day and $23 \%$ used it more than once a day, as shown in Table 14 . Each visit to the APP revealed to be of a short duration, lasting less than $5 \mathrm{~min}$ for $54 \%$ of the users or between $5-10$ min for $46 \%$ of the users (Table 15).

The most visited page of the Sharing Lisboa APP was the school progress page (85\%), in which the points obtained by each school were revealed, probably not only because most of the respondents were school staff but also because one of the main reasons to use Sharing Lisboa mentioned was to help the school (see Table A3). Individual progress pages and summary pages were also visited by a majority of the participants (69\%). Nonetheless, the only page all of the respondents visited was the Quizzes page, in which users could gain points by filling quizzes, as seen in Table A3. Regarding the Bonus and local shops, around half of the respondents did not visit the page. 
Regarding the level of satisfaction towards the pages visited, respondents were satisfied with the pages they mostly visited (Table 16), like Quizzes (85\%) and schools progress $(69 \%)$. However, respondents also revealed to be indifferent to some of the pages visited, such as the Individual progress page (46\%) and the Summary page $(54 \%)$, which might be indicative that the exclusive interest in using the APP was, once again, related with contributing to the school and not individual interests.

Table 11. Knowledge of Sharing Lisboa.

\begin{tabular}{ccc}
\hline & Knowledge of Sharing Lisboa & \\
\hline Friends/colleagues & 5 & $38 \%$ \\
\hline Panels at school & 4 & $31 \%$ \\
\hline School sessions & 3 & $23 \%$ \\
\hline Website & 1 & $8 \%$ \\
\hline Leaflet & 0 & $0 \%$ \\
\hline Local shops & 0 & $0 \%$ \\
\hline Other & 0 & $0 \%$ \\
\hline
\end{tabular}

Table 12. Motivation to join Sharing Lisboa.

\begin{tabular}{ccc}
\hline & Motives to Participate & \\
\hline $\begin{array}{c}\text { To help the school win a } \\
\text { reward }\end{array}$ & 12 & $63 \%$ \\
\hline $\begin{array}{c}\text { To learn about sustainable } \\
\text { behaviours }\end{array}$ & 7 & $37 \%$ \\
\hline Win bonus & 0 & $0 \%$ \\
\hline Other & 0 & $0 \%$ \\
\hline
\end{tabular}

Table 13. Level of easiness to register at Sharing Lisboa.

\begin{tabular}{ccc}
\hline & Level of Easiness to Register & \\
\hline 1 (extremely difficult) & 1 & $8 \%$ \\
\hline 2 & 0 & $0 \%$ \\
\hline 3 & 1 & $8 \%$ \\
\hline 4 & 4 & $31 \%$ \\
\hline 5 (extremely easy) & 7 & $54 \%$ \\
\hline
\end{tabular}

Table 14. Frequency of access to Sharing Lisboa.

\begin{tabular}{ccc}
\hline & Frequency of Use & \\
\hline More than once a day & 3 & $23 \%$ \\
\hline Every day & 5 & $38 \%$ \\
\hline $2-4$ times a week & 3 & $23 \%$ \\
\hline Once a week & 1 & $8 \%$ \\
\hline Every two weeks & 1 & $8 \%$ \\
\hline Once a month & 0 & $0 \%$ \\
\hline Less than once a month & 0 & $0 \%$ \\
\hline
\end{tabular}


Table 15. Duration of each access to Sharing Lisboa.

\begin{tabular}{ccc}
\hline & Average Time Per Visit & \\
\hline Less than 5 min & 7 & $54 \%$ \\
\hline $5-10$ min & 6 & $46 \%$ \\
\hline $11-20$ min & 0 & $0 \%$ \\
\hline More than 20 min & 0 & $0 \%$ \\
\hline
\end{tabular}

Table 16. Level of satisfaction with different features of Sharing Lisboa.

\begin{tabular}{|c|c|c|c|c|c|}
\hline $\begin{array}{c}\text { Level of Satisfaction Towards } \\
\text { Different Features of the Sharing } \\
\text { Lisboa APP }\end{array}$ & Unsatisfied & Not Satisfied & Indifferent & Satisfied & Very Satisfied \\
\hline Profile & $0 \%$ & $8 \%$ & $46 \%$ & $38 \%$ & $8 \%$ \\
\hline Schools & $0 \%$ & $0 \%$ & $31 \%$ & $46 \%$ & $23 \%$ \\
\hline Maps & $8 \%$ & $0 \%$ & $38 \%$ & $46 \%$ & $8 \%$ \\
\hline Progress & $8 \%$ & $0 \%$ & $46 \%$ & $31 \%$ & $15 \%$ \\
\hline Settings & $0 \%$ & $0 \%$ & $46 \%$ & $38 \%$ & $15 \%$ \\
\hline APP sharing & $15 \%$ & $15 \%$ & $31 \%$ & $31 \%$ & $8 \%$ \\
\hline Talk with us & $8 \%$ & $15 \%$ & $38 \%$ & $31 \%$ & $8 \%$ \\
\hline Tutorial & $0 \%$ & $0 \%$ & $69 \%$ & $15 \%$ & $15 \%$ \\
\hline Glossary & $0 \%$ & $8 \%$ & $69 \%$ & $15 \%$ & $8 \%$ \\
\hline Sharing Cities & $0 \%$ & $0 \%$ & $62 \%$ & $31 \%$ & $8 \%$ \\
\hline Case study & $0 \%$ & $8 \%$ & $46 \%$ & $46 \%$ & $0 \%$ \\
\hline Terms and conditions & $0 \%$ & $0 \%$ & $77 \%$ & $15 \%$ & $8 \%$ \\
\hline Summary page & $0 \%$ & $0 \%$ & $54 \%$ & $38 \%$ & $8 \%$ \\
\hline Quizzes & $0 \%$ & $0 \%$ & $15 \%$ & $62 \%$ & $23 \%$ \\
\hline Bonus & $0 \%$ & $0 \%$ & $38 \%$ & $46 \%$ & $15 \%$ \\
\hline Shops & $0 \%$ & $8 \%$ & $38 \%$ & $38 \%$ & $15 \%$ \\
\hline
\end{tabular}

Overall, respondents considered, as seen in Table 17, that connecting with external accounts (38\%) was one of the most difficult aspects of Sharing Lisboa usage, while 15\% and $31 \%$ indicated that gaining mobility and energy consumption points, respectively, was extremely difficult. Of them, 69\% were indifferent to the local shops' check-in processes and $54 \%$ to using the bonus feature. For $69 \%$ of the respondents, it was easy or extremely easy to navigate and explore the APP. Additionally, 85\% revealed it was easy or extremely easy to fill a quiz, 38\% considered it was easy to use a bonus. Regarding gaining points, $62 \%$ and $31 \%$ indicated that it was easy or extremely easy to gain mobility and energy consumption points, respectively.

When asked about what type of other local shops they would like to be included in Sharing Lisboa, these include (Table 18): bookstores and stationery (85\%), museums (62\%), followed by electronic devices stores, Apparel and shoes, supermarkets and mini-markets and local produce shops (54\%). The majority of respondents would recommend Sharing Lisboa to others $(77 \%)$. 
Table 17. Level of easiness to use different features of Sharing Lisboa.

\begin{tabular}{|c|c|c|c|c|c|}
\hline $\begin{array}{c}\text { Level of Easiness of Using the Features of } \\
\text { Sharing Lisboa APP }\end{array}$ & $\begin{array}{l}\text { Extremely } \\
\text { Difficult }\end{array}$ & Difficult & Indifferent & Easy & Extremely Easy \\
\hline \multirow{2}{*}{ Navigate and explore } & 0 & 1 & 3 & 5 & 4 \\
\hline & $0 \%$ & $8 \%$ & $23 \%$ & $38 \%$ & $31 \%$ \\
\hline \multirow{2}{*}{ Connect with other accounts (e.g., google fit) } & 0 & 5 & 4 & 3 & 1 \\
\hline & $0 \%$ & $38 \%$ & $31 \%$ & $23 \%$ & $8 \%$ \\
\hline \multirow{2}{*}{ Shops Check-in } & 0 & 2 & 9 & 2 & 0 \\
\hline & $0 \%$ & $15 \%$ & $69 \%$ & $15 \%$ & $0 \%$ \\
\hline \multirow{2}{*}{ Fill a quizz } & 0 & 0 & 2 & 6 & 5 \\
\hline & $0 \%$ & $0 \%$ & $15 \%$ & $46 \%$ & $38 \%$ \\
\hline \multirow{2}{*}{ Use bonus } & 0 & 1 & 7 & 5 & 0 \\
\hline & $0 \%$ & $8 \%$ & $54 \%$ & $38 \%$ & $0 \%$ \\
\hline \multirow{2}{*}{ Win points—sustainable mobility } & 2 & 1 & 2 & 4 & 4 \\
\hline & $15 \%$ & $8 \%$ & $15 \%$ & $31 \%$ & $31 \%$ \\
\hline \multirow{2}{*}{ Win points-energy consumption } & 4 & 0 & 5 & 3 & 1 \\
\hline & $31 \%$ & $0 \%$ & $38 \%$ & $23 \%$ & $8 \%$ \\
\hline
\end{tabular}

Table 18. Types of businesses users would like to be included in Sharing Lisboa.

\begin{tabular}{ccc}
\hline Type of Businesses to Include in Sharing Lisboa APP & \\
\hline Toys & 2 & $15 \%$ \\
\hline Bookstores and Stationery & 11 & $85 \%$ \\
\hline Electronic devices & 7 & $54 \%$ \\
\hline Sports equipment & 5 & $38 \%$ \\
\hline Museums & 8 & $62 \%$ \\
\hline Apparel and shoes & 7 & $54 \%$ \\
\hline Cosmetic & 0 & $0 \%$ \\
\hline Supermarkets & 7 & $54 \%$ \\
\hline Mini-supermarket and local produce shops & 7 & $54 \%$ \\
\hline Butcher and fishmongers & 4 & $31 \%$ \\
\hline Movies & 6 & $46 \%$ \\
\hline Concerts and festivals & 6 & $46 \%$ \\
\hline Other & 0 & $0 \%$ \\
\hline Total & 13 & $100 \%$ \\
\hline
\end{tabular}

\section{Discussion}

Several other gamification-based strategies to promote behaviour change have been addressed in several other programs similar to that of Sharing Cities, either focusing on energy efficiency or sustainable mobility. Sharing Lisboa addresses these two fields in the same gamification tool to incentive behaviour change. Over its six months' trial in three schools, 1260 users registered in the APP and over 17,000 transactions were made, in line with results obtained with the Bellidea APP [19] deployed in Switzerland and those of the GAIA Project [21] that involved 3000 students and 200 educators in Greece, Italy and Sweden. The main reason to participate in Sharing Lisboa was the ability to help one school win a prize, which is in line with the findings obtained from the focus groups conducted with the citizens, that stood out that the existence of a common cause that they 
could contribute for would motivate more the participation instead of personal gains. The majority of participants are extremely concerned $(59 \%)$ with energy consumption at home and consider that it is extremely important to save energy $(70 \%)$. Nonetheless, results indicate that after using Sharing Lisboa APP parents $(78 \%)$ and school staff $(72 \%)$ adopted some energy-saving behaviours at home that they did not before, such as replacing an appliance with a more efficient one or using only eco programs with the washing machine or dishwasher. This is in line with results obtained in the ChArGED project [22], in which participants self-reported improvements in energy-saving behaviours adopted in the work environment.

Regarding mobility, the main transport mode for $53 \%$ of the users is walking and $18 \%$ use different transport modes. Their motives for using these transport modes are its health and environmental benefits, but $81 \%$ mention that it is easy for them to use such a transport mode and $41 \%$ because it is cheapest. The three schools are located, as previously mentioned, in the demonstration area of the Sharing Cities program, which includes residential and old neighbourhoods, in which parking a car can be difficult, which might be indicative of why, aside from already awareness of environmental issues, sustainable transport modes are already used by most participants. Nonetheless, $56 \%$ of the parents and $67 \%$ of school staff mentioned that they used the car less after starting to participate in Sharing Lisboa, in line with results obtained with the Traffic Snake Game Network, in which sustainable trips went from $68 \%$ to $78 \%$ during the game campaign.

Such a scheme like the one developed in Lisbon within the context of the Sharing Cities program was ground-breaking, since it enabled the city with the creation of a tool with the potential to, though gamification strategies, support and incentive behaviour change and the adoption of energy-efficient behaviours at a building and/or residential level and sustainable mobility options. The definition and design of the concept and the development of the APP was a time-consuming process that involved, as previously mentioned, several steps and the involvement of different stakeholders and, most importantly, the participation of the citizens. However, the approach enabled developing and deploying a tool for a more sustainable city taking into account its users' perceptions and their needs. Nonetheless, one of the limitations of this approach was that in the end the DSM was limited to school community involvement, even though a strong effort was made to involve the surrounding neighbourhood and community, which also led to limited results in the community. Furthermore, the deployment of the DSM in several schools implied the need to have a full-time human resource dedicated to the promotion, implementation of Sharing Lisboa and engagement with the students, teacher and school staff. However, the existence of this human resource was crucial increasing awareness of the school community and for its successful engagement and participation. Regarding the APP design and functioning, budget and time constraints did not allow the inclusion of some features, such as pop-up notifications that would allow reminding users to use the app or to notify outside the APP of new challenges, for example. The collection of user socio-demographic data was not possible to collect due to new RGPD guidelines, as previously mentioned.

Through gamification, Sharing Lisboa was able to increase awareness in sustainability and energy efficiency and incentive behaviour change, while creating a community within the city, promoting local and small businesses increasing engagement between citizens and the municipality/parishes. Considering the results obtained with this pilot, mainly in what concerns the adoption of energy-saving behaviours at home and of walking or cycling, if Sharing Lisboa was expanded to the whole city, the potential energy savings both at household and transportation level would be crucial for the mitigation of local pollutants emissions. Consequently, the adoption of such a tool at a city level, has the potential to change the layout of a city, the way people move, behave and use the different features and services of the city and, therefore, improve the quality of life of the citizens and transform cities into more liveable places. However, and taking into account inputs collected from the citizens over the design and development process of Sharing Lisboa, such a tool must 
be simple to use and adopt, supported by awareness campaigns and information on why they are important for the city.

\section{Conclusions}

After the implementation of the Sharing Lisboa pilot, it is possible to ascertain that it is definitely a tool that can increase the engagement of citizens with municipality/parishes. However, some important factors need to be addressed for this expansion to take place, such as developing a business model that is both profitable and useful for the city, businesses and citizens, understanding where will the investment come from, how to attract users and create a highly competing service and APP that attracts the citizen. Besides promoting proximity between the citizen and municipality, such a tool can also be used to promote awareness on sustainable behaviours, promote local businesses, using immediate rewards/gratifications to incentive engagement. The format of Sharing Lisboa can also be adjusted to other formats and contexts, such as deployment within the municipality buildings/departments, internal use in companies, etc., and replication in other cities. However, it is essential to develop and define a business model that is profitable and that will allow the scale-up of the scheme to the city or replicating it in other cities, since investment will be required for infrastructure and management of such a market. Furthermore, besides developing profitable business models, it is of crucial importance to develop a tool that gains the general citizen interest attracting not only highly aware citizens or those already involved in similar environmentally conscious activities.

Such a service like the one offered by Sharing Lisboa has the potential to be a vehicle of change not only in what concerns people's behaviour but also in the overall functioning of the city, leading to a more sustainable living context with decreases in energy consumption and pollutants emissions and to the improvement of citizen's quality of life. Such a scheme can integrate existing and new solutions for communication and dissemination purposes and, most essentially, to educate citizens. Furthermore, it can enable developing new services building upon existing systems and platforms, incentivising the sharing of data among its participants.

Author Contributions: Conceptualization, C.C.R., P.B.; methodology, C.C.R.; formal analysis, C.C.R.; investigation, C.C.R.; data curation, C.C.R.; writing—original draft preparation, C.C.R., P.B.; writingreview and editing, C.C.R., P.B.; project administration, C.C.R. All authors have read and agreed to the published version of the manuscript.

Funding: This research was funded by the European Union's Horizon 2020 research and innovation program under Grant Agreement No. 691895 SHAR-LLM ("Sharing Cities"). The authors acknowledge Fundação para a Ciência e Tecnologia for IN+ Strategic Project UID/EEA/50009/2019 and for contract CEECIND/02589/2017.

Data Availability Statement: Data was collected under the Sharing Cities Lighthouse program and most particularly within the Sharing Lisboa APP context. While the participants gave consent on the collection of data for APP usage and questionnaires, the consent provided was to analyse data in an anonymous way and raw data should be maintained private.

Acknowledgments: The authors would like to acknowledge the support of all the partners of the Sharing Cities Program namely Lisbon Municipality, Lisboa E-Nova, EDP-D, Reabilita, EMEL, CEiiA, Altice Labs for their contribution and participation in the development and implementation of Sharing Lisboa. Furthermore, acknowledgements are also due to Future Cities Catapult for their supervision and guidance on the development of the Sharing Lisboa concept, co-design sessions with citizens and stakeholders and support during the deployment of the DSM. Acknowledgments are also due to Altice Labs for development of the Sharing Lisboa APP.The authors would also like to acknowledge the three schools that accepted and embraced the challenge of participating in this pilot.

Conflicts of Interest: The authors declare no conflict of interest. The funders had no role in the design of the study; in the collection, analyses, or interpretation of data; in the writing of the manuscript; or in the decision to publish the results. 


\section{Appendix A}

Table A1. Energy-saving behaviours adopted after using Sharing Lisboa APP by type of user.

\begin{tabular}{|c|c|c|c|c|c|c|c|c|c|c|c|c|}
\hline \multicolumn{2}{|c|}{$\begin{array}{l}\text { Behaviours Started } \\
\text { Practicing after Sharing } \\
\text { Lisboa Experience }\end{array}$} & $\begin{array}{c}\text { I } \\
\text { Always } \\
\text { Turn } \\
\text { off the } \\
\text { Lights } \\
\text { When } \\
\text { Leav- } \\
\text { ing a } \\
\text { Room }\end{array}$ & $\begin{array}{c}\text { I Only } \\
\text { use the } \\
\text { Washing } \\
\text { Ma- } \\
\text { chine/ } \\
\text { Dish- } \\
\text { washer } \\
\text { When in } \\
\text { Full } \\
\text { Capacity }\end{array}$ & $\begin{array}{c}\text { I } \\
\text { Changed } \\
\text { old } \\
\text { Lamp } \\
\text { Bulbs } \\
\text { for more } \\
\text { Efficient } \\
\text { Ones } \\
\text { (e.g., } \\
\text { Led) }\end{array}$ & $\begin{array}{c}\text { I } \\
\text { Always } \\
\text { Turn off } \\
\text { Elec- } \\
\text { tronic } \\
\text { Devices } \\
\text { (e.g., tv) } \\
\text { from the } \\
\text { Plug }\end{array}$ & $\begin{array}{c}\text { I } \\
\text { Always } \\
\text { Turn off } \\
\text { Appli- } \\
\text { ances } \\
\text { (e.g., } \\
\text { Dish- } \\
\text { washer) } \\
\text { from the } \\
\text { Plug }\end{array}$ & $\begin{array}{c}\text { I } \\
\text { Always } \\
\text { Choose } \\
\text { New Ap- } \\
\text { pliances } \\
\text { in Accor- } \\
\text { dance } \\
\text { with En- } \\
\text { ergetic } \\
\text { evalua- } \\
\text { tion }\end{array}$ & $\begin{array}{l}\text { I do not } \\
\text { Leave } \\
\text { the } \\
\text { Phone } \\
\text { Charger } \\
\text { Plugged }\end{array}$ & $\begin{array}{l}\text { Changed a } \\
\text { Non- } \\
\text { Efficient } \\
\text { Appliance, } \\
\text { Device or } \\
\text { Equip- } \\
\text { ment with } \\
\text { a More } \\
\text { Efficient } \\
\text { One }\end{array}$ & $\begin{array}{c}\text { Only } \\
\text { Use } \\
\text { Eco } \\
\text { pro- } \\
\text { grams } \\
\text { to } \\
\text { Wash } \\
\text { Clothes } \\
\text { and } \\
\text { Dishes }\end{array}$ & $\begin{array}{l}\text { Other: } \\
\text { I Do } \\
\text { Not } \\
\text { Throw } \\
\text { Garbage } \\
\text { in the } \\
\text { Floor } \\
\text { Any- } \\
\text { more }\end{array}$ & $\begin{array}{c}\text { Total of } \\
\text { Re- } \\
\text { spon- } \\
\text { dents }\end{array}$ \\
\hline \multirow{7}{*}{ Students } & \multirow{2}{*}{ At home } & 1 & 0 & 0 & 3 & 0 & 0 & 2 & 0 & 0 & 0 & 3 \\
\hline & & $33 \%$ & $0 \%$ & $0 \%$ & $100 \%$ & $0 \%$ & $0 \%$ & $67 \%$ & $0 \%$ & $0 \%$ & $0 \%$ & - \\
\hline & \multirow{2}{*}{ At school } & 0 & 0 & 0 & 0 & 0 & 0 & 0 & 0 & 0 & 1 & 3 \\
\hline & & $0 \%$ & $0 \%$ & $0 \%$ & $0 \%$ & $0 \%$ & $0 \%$ & $0 \%$ & $0 \%$ & $0 \%$ & $33 \%$ & - \\
\hline & \multirow{2}{*}{$\begin{array}{c}\text { Home and } \\
\text { School }\end{array}$} & 2 & 0 & 0 & 0 & 0 & 0 & 1 & 0 & 0 & 0 & 3 \\
\hline & & $67 \%$ & $0 \%$ & $0 \%$ & $0 \%$ & $0 \%$ & $0 \%$ & $33 \%$ & $0 \%$ & $0 \%$ & $0 \%$ & - \\
\hline & \multirow{2}{*}{ At home } & 2 & 13 & 14 & 13 & 11 & 13 & 9 & 8 & 14 & & 18 \\
\hline \multirow{5}{*}{$\begin{array}{l}\text { School } \\
\text { staff }\end{array}$} & & $11 \%$ & $72 \%$ & $78 \%$ & $72 \%$ & $61 \%$ & $72 \%$ & $50 \%$ & $44 \%$ & $78 \%$ & $0 \%$ & - \\
\hline & \multirow{2}{*}{ At school } & 1 & 0 & 0 & 0 & 0 & 0 & 0 & 0 & 0 & 0 & 18 \\
\hline & & $6 \%$ & $0 \%$ & $0 \%$ & $0 \%$ & $0 \%$ & $0 \%$ & $0 \%$ & $0 \%$ & $0 \%$ & $0 \%$ & - \\
\hline & \multirow{2}{*}{$\begin{array}{c}\text { Home and } \\
\text { School }\end{array}$} & 13 & 1 & 0 & 1 & 1 & 0 & 3 & 0 & 0 & 0 & 18 \\
\hline & & $72 \%$ & $6 \%$ & $0 \%$ & $6 \%$ & $6 \%$ & $0 \%$ & $17 \%$ & $0 \%$ & $0 \%$ & $0 \%$ & - \\
\hline \multirow{2}{*}{\multicolumn{2}{|c|}{ Parents }} & 4 & 3 & 4 & 2 & 1 & 4 & 5 & 6 & 5 & 0 & 7 \\
\hline & & $57 \%$ & $43 \%$ & $57 \%$ & $29 \%$ & $14 \%$ & $57 \%$ & $71 \%$ & $86 \%$ & $71 \%$ & $0 \%$ & - \\
\hline \multirow{2}{*}{\multicolumn{2}{|c|}{ Neighb. resident }} & 0 & 0 & 0 & 2 & 1 & 0 & 2 & 0 & 0 & 0 & 3 \\
\hline & & $0 \%$ & $0 \%$ & $0 \%$ & $67 \%$ & $33 \%$ & $0 \%$ & $67 \%$ & $0 \%$ & $0 \%$ & $0 \%$ & - \\
\hline \multirow{2}{*}{\multicolumn{2}{|c|}{ Other }} & 1 & 1 & 2 & 1 & 1 & 1 & 2 & 1 & 2 & 0 & 2 \\
\hline & & $50 \%$ & $50 \%$ & $100 \%$ & $50 \%$ & $50 \%$ & $50 \%$ & $100 \%$ & $50 \%$ & $100 \%$ & $0 \%$ & - \\
\hline
\end{tabular}

Table A2. Motives for behaviour changes by type of user.

\begin{tabular}{|c|c|c|c|c|c|}
\hline $\begin{array}{c}\text { Why Did You } \\
\text { Change } \\
\text { Behaviours }\end{array}$ & $\begin{array}{l}\text { Learned the } \\
\text { Importance of } \\
\text { Using Energy } \\
\text { in a More } \\
\text { Efficient Way }\end{array}$ & $\begin{array}{l}\text { Learned the } \\
\text { Importance of } \\
\text { Using Less } \\
\text { Pollutant } \\
\text { Transportation } \\
\text { Mode }\end{array}$ & $\begin{array}{l}\text { To Help the } \\
\text { School I } \\
\text { Supported }\end{array}$ & $\begin{array}{l}\text { To Gain More } \\
\text { Points }\end{array}$ & $\begin{array}{c}\text { I Did Not Change } \\
\text { Behaviour }\end{array}$ \\
\hline \multirow{2}{*}{ Students } & 3 & 3 & 3 & 0 & 0 \\
\hline & $100 \%$ & $100 \%$ & $100 \%$ & $0 \%$ & $0 \%$ \\
\hline \multirow{2}{*}{ Parents } & 6 & 4 & 3 & 4 & 3 \\
\hline & $67 \%$ & $44 \%$ & $33 \%$ & $44 \%$ & $33 \%$ \\
\hline \multirow{2}{*}{ School Staff } & 16 & 11 & 8 & 5 & 0 \\
\hline & $89 \%$ & $61 \%$ & $44 \%$ & $28 \%$ & $0 \%$ \\
\hline \multirow{2}{*}{ Neighb. resident } & 2 & 2 & 3 & 2 & 2 \\
\hline & $33 \%$ & $33 \%$ & $50 \%$ & $33 \%$ & $33 \%$ \\
\hline \multirow{2}{*}{ Other } & 2 & 2 & 2 & 1 & 0 \\
\hline & $50 \%$ & $50 \%$ & $50 \%$ & $25 \%$ & $0 \%$ \\
\hline
\end{tabular}


Table A3. Access to different features of Sharing Lisboa.

\begin{tabular}{cccc}
\hline $\begin{array}{c}\text { Usage of Different Features } \\
\text { of the Sharing Lisboa APP }\end{array}$ & I Did Not Visit The Page & $\begin{array}{c}\text { I Did Not Visit the Page. I } \\
\text { Did Not Know About It. }\end{array}$ & I Visited the Page \\
\hline Profile & $54 \%$ & $0 \%$ & $46 \%$ \\
\hline Schools & $15 \%$ & $0 \%$ & $85 \%$ \\
\hline Maps & $38 \%$ & $0 \%$ & $62 \%$ \\
\hline Progress & $23 \%$ & $8 \%$ & $69 \%$ \\
\hline Settings & $38 \%$ & $0 \%$ & $62 \%$ \\
\hline APP sharing & $38 \%$ & $8 \%$ & $54 \%$ \\
\hline Talk with us & $54 \%$ & $8 \%$ & $38 \%$ \\
\hline Tutorial & $69 \%$ & $0 \%$ & $31 \%$ \\
\hline Glossary & $69 \%$ & $8 \%$ & $23 \%$ \\
\hline Sharing Cities & $46 \%$ & $8 \%$ & $46 \%$ \\
\hline Case study & $46 \%$ & $23 \%$ & $31 \%$ \\
\hline Terms and conditions & $54 \%$ & $0 \%$ & $46 \%$ \\
\hline Summary page & $23 \%$ & $8 \%$ & $69 \%$ \\
\hline Quizzes & $0 \%$ & $0 \%$ & $100 \%$ \\
\hline Bonus & $46 \%$ & $0 \%$ & $54 \%$ \\
\hline Shops & $62 \%$ & $0 \%$ & $38 \%$ \\
\hline
\end{tabular}

\section{References}

1. PORDATA PORDATA-População Residente: Total e Por Grandes Grupos Etários. Available online: https:/ /www.pordata.pt/ Municipios/Populaç ao+residente+total+e+por+grandes+grupos+etários-390 (accessed on 21 January 2021).

2. EC 2030 Climate \& Energy Framework I Climate Action. Available online: https:/ / ec.europa.eu/clima/policies/strategies/2030 en (accessed on 21 January 2021).

3. EAFO Passenger Cars EAFO. 2020. Available online: https://www.eafo.eu/vehicles-and-fleet/m1 (accessed on 21 January 2021).

4. Akande, A.; Cabral, P.; Gomes, P.; Casteleyn, S. The Lisbon ranking for smart sustainable cities in Europe. Sustain. Cities Soc. 2019, 44, 475-487. [CrossRef]

5. Opendatasoft Insights on Smart Cities: Interview with Ruthbea Yesner. Available online: https://www.opendatasoft.com/blog/ data-as-a-smart-city-asset-the-importance-of-data-sharing-for-cities-and-their-solution-partners (accessed on 21 January 2021).

6. Lim, C.; Kim, K.J.; Maglio, P.P. Smart cities with big data: Reference models, challenges, and considerations. Cities 2018, 82, 86-99. [CrossRef]

7. Axelsson, K.; Granath, M. Stakeholders' stake and relation to smartness in smart city development: Insights from a Swedish city planning project. Gov. Inf. Q. 2018, 35, 693-702. [CrossRef]

8. Dahal, K.; Niemelä, J. Initiatives towards Carbon Neutrality in the Helsinki Metropolitan Area. Climate 2016, 4, 36. [CrossRef]

9. ITU-T Key Performance Indicators Definitions for Smart Cities, Focus Group Technical Report. Available online: https:// www.itu.int/en/ITU-T/ssc/united/Documents/SmartSustainableCities-KPI-ConceptNote-U4SSC-website.pdf (accessed on 21 January 2021).

10. ISO/IEC JTC. Information technology ISO/IEC JTC 1 Smart Cities. 2015. Available online: https:/ / www.iso.org/files/live/sites/ isoorg/files/developing_standards/docs/en/smart_cities_report-jtc1.pdf (accessed on 21 January 2021).

11. Simonofski, A.; Asensio, E.S.; de Smedt, J.; Snoeck, M. Citizen participation in smart cities: Evaluation framework proposal In Proceedings of the 2017 IEEE 19th Conference on Business Informatics, CBI 2017, Thessaloniki, Greece, 24-27 July 2017; Volume 1, pp. 227-236.

12. Tonks, E.; Lockie, S. Urban Transformation: From Single-Point Solutions to Systems Innovation. Climate 2020, 8, 17. [CrossRef]

13. Caird, S.; Hudson, L.; Kortuem, G. A Tale of Evaluation and Reporting in UK Smart Cities; The Open University: Milton Keynes, UK, 2016.

14. Hassan, L.; Hamari, J. Gameful civic engagement: A review of the literature on gamification of e-participation. Gov. Inf. Q. 2020, 37, 101461. [CrossRef]

15. Liu, Z.; Wang, Y.; Xu, Q.; Yan, T. Related content Study on smart city construction of Jiujiang based on IOT technology Smart city planning under the climate change condition Interactive Environment Design in Smart City Gamification in the context of smart cities. In Proceedings of the International Conference on Applied Sciences, Hunedoara, Romania, 10-12 May 2017. 
16. Orland, B.; Ram, N.; Lang, D.; Houser, K.; Kling, N.; Coccia, M. Saving energy in an office environment: A serious game intervention. Energy Build. 2014, 74, 43-52. [CrossRef]

17. Holleis, P.; Luther, M.; Broll, G.; Cao, H.; Koolwaaij, J.; Peddemors, A.; Ebben, P.; Wibbels, M.; Jacobs, K. TRIPZOOM: A System to Motivate Sustainable Urban Mobility. In Proceedings of the SMART 2012: The First International Conference on Smart Systems, Devices and Technologies, Stuttgart, Germany, 27 May-1 June 2012.

18. DTV Consultants Traffic Snake Game. Available online: https:/ / www.trafficsnakegame.eu/ (accessed on 16 February 2021).

19. Cellina, F.; Granato, P. Co-designing a persuasive app promoting a less car-dependant community Introducing the Bellidea living lab Institute for Applied Sustainability to the Built Environment-ISAAC. In Proceedings of the 5th European Conference on Behaviour and Energy Efficiency, Zurich, Switzerland, 6-7 September 2018.

20. Fraternali, P.; Luis, S.; Gonzalez, H. enCOMPASS, demonstrating the impact of gamification and persuasive visualizations for energy saving. Energy Inform. 2019. Available online: https://re.public.polimi.it/retrieve/handle/11311/1107974/429383 /enCOMPASS_demonstrating_the_impact_of\%20gamification.pdf (accessed on 16 February 2021).

21. Gaia Gaia Project—an H2020 EU Project about Energy Awareness and Green Education. Available online: http:/ / gaia-project.eu/ index.php/en/homepage-3/ (accessed on 16 February 2021).

22. CHARGED H2020-EE-11-2015 Innovation Action CleAnweb Gamified Energy Disaggregation Lessons Learnt. Available online: http://www.charged-project.eu/sites/default/files/publications/ChArGED_LessonsLearned.pdf (accessed on 16 February 2021).

23. FEEdBACk FEEdBACk Project-The ECOplay App for Saving Energy. Available online: https://feedback-project.eu/news / webinar:-feedback-project----the-ecoplay-app-for-saving-energy--32 (accessed on 16 February 2021).

24. Saunders, T.; Baeck, P. Rethinking Smart Cities From the Ground Up. Nesta Technical Report. 2015. Available online: https: //media.nesta.org.uk/documents/rethinking_smart_cities_from_the_ground_up_2015.pdf. (accessed on 21 January 2021).

25. Murcotts Driver Behaviour Training-Murcotts. Available online: https://www.murcotts.edu.au/corporate-fleet/driverbehaviour-training/ (accessed on 21 January 2021).

26. Barkenbus, J.N. Eco-driving: An overlooked climate change initiative. Energy Policy 2010, 38, 762-769. [CrossRef]

27. SHARING CITIES. Available online: http:/ / www.sharingcities.eu/ (accessed on 21 January 2021). 